OPEN ACCESS

\title{
Red-Emitting Coatings for Multifunctional UV/Red Emitting LEDs Applied in Plant Circadian Rhythm Control
}

To cite this article: Airton G. Bispo Jr et al 2020 ECS J. Solid State Sci. Technol. 9016008

View the article online for updates and enhancements.

\section{Visualize the processes inside your battery!} Discover the new ECC-0pto-10 and PAT-Cell-0pto-10 test cells!
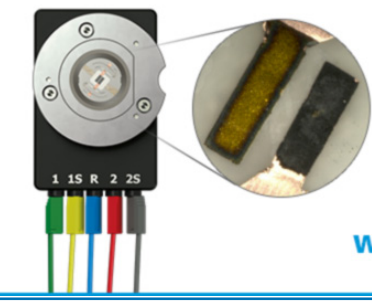

- Battery test cells for optical characterization

- High cycling stability, advanced cell design for easy handling

- For light microscopy and Raman spectroscopy

www.el-cell.com +49(0) 4079012734 sales@el-cell.com

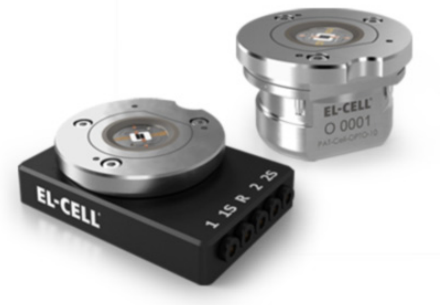




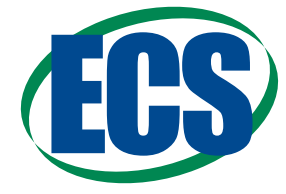

\title{
Red-Emitting Coatings for Multifunctional UV/Red Emitting LEDs Applied in Plant Circadian Rhythm Control
}

\author{
Airton G. Bispo-Jr, $\bigodot^{1,2}$ Sergio A. M. Lima, ${ }^{1,2}$ Luís D. Carlos, ${ }^{3}$ Rute A. S. Ferreira, ${ }^{3, z}$ \\ and Ana M. Pires $1,2, \mathrm{z}$ \\ ${ }^{1}$ São Paulo State University (Unesp), School of Technology and Sciences, Presidente Prudente, SP 19060-900, Brazil \\ ${ }_{2}^{2}$ São Paulo State University (Unesp), Institute of Biosciences, Humanities and Exact Sciences, São José do Rio Preto, \\ SP 15054-000, Brazil \\ ${ }^{3}$ Department of Physics and CICECO - Aveiro Institute of Materials, University of Aveiro, 3810-193 Aveiro, Portugal
}

\begin{abstract}
Multifunctional light-emitting diodes (LEDs) formed by coating deep-UV-emitting $(<300 \mathrm{~nm})$ LED chips with downshifting phosphors are of great interest for applications in indoor farms as both antibacterial (UV radiation) and photosynthetic agent (red light). Challenges include the fabrication of high-brightness downshifting converter films with controlled thickness excited in the deep-UV spectral region. We address it by optimizing the amount of $\mathrm{Ba}_{2} \mathrm{SiO}_{4}$ : $\mathrm{Eu}(\mathrm{III})$ red-emitting phosphor dispersed in poly (methyl)methacrylate (PMMA), yielding luminescent films with tunable thickness. Taking advantage of the intra- $4 f^{6}$ transitions, the $\mathrm{Eu}$ (III) luminescence is used as local probe, pointing out the presence of 8 non-equivalent local sites for the lanthanides. PMMA enables the processing of flexible films and simultaneously acts as a selective filter to deep-UV radiation, controlling the amount of UV radiation for indoor farm applications. Moreover, after the dispersion in PMMA, the Eu(III)-based luminescence remains analogous to that of the isolated phosphor with an absolute emission quantum yield of $0.11 \pm 0.01$, confirming that $\mathrm{Ba}_{2} \mathrm{SiO}_{4}: \mathrm{Eu}(\mathrm{III}) / \mathrm{PMMA}$ films display desirable features to be used as coatings of deep-UV emitting LEDs toward multifunctional devices for indoor farm application.

(C) The Author(s) 2019. Published by ECS. This is an open access article distributed under the terms of the Creative Commons Attribution 4.0 License (CC BY, http://creativecommons.org/licenses/by/4.0/), which permits unrestricted reuse of the work in any medium, provided the original work is properly cited. [DOI: 10.1149/2.0122001JSS]

(cc) BY
\end{abstract}

Manuscript submitted July 29, 2019; revised manuscript received September 4, 2019. Published September 20, 2019. This paper is part of the JSS Focus Issue on Recent Advances in Wide Bandgap III-Nitride Devices and Solid State Lighting: A Tribute to Isamu Akasaki.

After just over two decades since the first commercialization, ${ }^{1}$ white light-emitting diodes (WLEDs) became the main white-light source for electronic devices (backlighting for displays, digital cameras, security equipment, mobile phone, etc.) and lighting, namely indoor (offices, homes, shops) and outdoor (streets, traffic signals) applications, ${ }^{2,3}$ being estimated to achieve nearly $60 \%$ of penetration in the lighting market in $2020 .^{4,5}$ Nonetheless, their commercial use is not limited to lighting since the current concern on improving life quality is catalyzing the solid-state lighting technology to come up with multifunctional light-emitting diodes (LEDs) that regulate human and plant circadian rhythm, as highlighted in Table I. ${ }^{6-13}$

In what concerns plant growth, the regulation of the circadian rhythm by light exposition from LEDs appears as an option to enhance the biomass production rate, especially in indoor farms, as an attractive alternative to supply the food world demand. ${ }^{14}$ In this case, the quality of the produced biomass depends on the light source characteristics, such as wavelength and intensity. ${ }^{15}$ Taking into account the impact of the emission wavelength on the plant circadian rhythm, red light is the most suitable one to regulate the photoreceptor phytochrome, that, in its turn, is directly correlated with photosynthesis, germination, flowering, as well as aerial architectural development. ${ }^{16}$ Extra UV radiation $(\sim 250 \mathrm{~nm})$ would also make a worthwhile contribution to food production since low doses of deep-UV radiation $\left(40 \mathrm{~mJ} . \mathrm{cm}^{-2}\right)^{17}$ are helpful to disinfection, water treatment, and purification by inactivating bacteria, spores, and viruses. ${ }^{17-19}$ It is worth pointing out it is essential to dose the amount of UV radiation, avoiding disturbs in the natural plant growth. ${ }^{20}$

Currently, deep-UV radiation is not applied in indoor farms due to the low external quantum efficiency (EQE) of deep-UV emitting LEDs, making its use quite expensive. The disinfection process in indoor farms is made chemically (ethanol, bleach, quaternary ammonium chloride salt, hydrogen peroxide) or physically (soil solarization and steam sterilization) prior the cultivation and then, the sanitizing control is done only by keeping the environment clean, to which may lead to contaminations. ${ }^{21}$ In this regard, we note that if the indoor farm is exposed to controlled doses of deep-UV radiation, its environment could be free of microorganisms over the time of use. There-

zE-mail: rferreira@ua.pt; ana.maria@unesp.br fore, the combination of a deep-UV emitting LED (250 nm) and a deep-UV-to-red downshifting converter phosphor allows fabricating a multifunctional prototype with controlled UV radiation emission and simultaneous red light suitable for indoor farming, Figure 1.

To accomplish the multifunctional device fabrication, two main challenges need to be addressed: i) fabrication of compact and higher output power deep-UV LEDs and (ii) choice of efficient monochromatic downshifting phosphors easily processed as coatings with adjustable thickness. Regarding issue (i), some progress has been achieved in the last 10 years, ${ }^{22}$ despite low energy conversion efficiency $(1 \%),{ }^{23}$ so that, this is still a challenge. In this study, we propose to address challenge (ii), in particular, by the utilization of the $\mathrm{Ba}_{2} \mathrm{SiO}_{4}: \mathrm{Eu}$ (III) phosphor, whose $\mathrm{Ba}_{2} \mathrm{SiO}_{4}$ matrix is well-known for LED application. ${ }^{24,25}$ The rationales behind its selection lie on the low phonon frequency of the matrix $\left(\sim 900 \mathrm{~cm}^{-1}\right)$, and high thermal stability (up to $1000^{\circ} \mathrm{C}$, with no changes in the structure or decom-

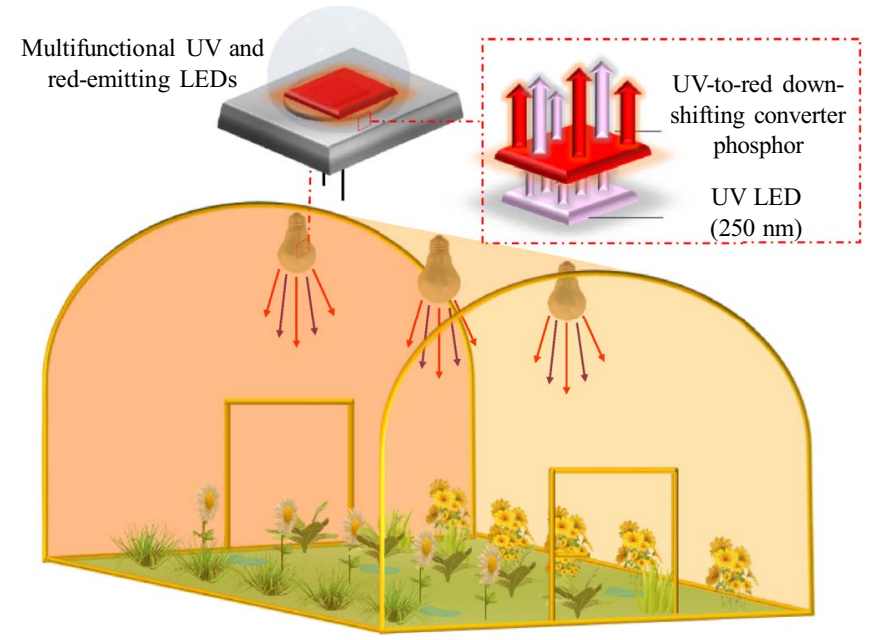

Figure 1. Scheme of the UV and red-emitting multifunctional LED architecture for a potential application in indoor farming. 
Table I. LED emission features for human and plant circadian rhythm control.

\begin{tabular}{|c|c|c|c|c|}
\hline $\begin{array}{l}\text { LED maximum } \\
\text { emission } \\
\text { wavelength }\end{array}$ & $\begin{array}{c}\text { Human circadian rhythm } \\
\text { control }\end{array}$ & $\begin{array}{l}\text { Application for human } \\
\text { healthy }\end{array}$ & $\begin{array}{l}\text { Plant circadian rhythm } \\
\text { control }\end{array}$ & $\begin{array}{l}\text { Application for plant and } \\
\text { food technology }\end{array}$ \\
\hline Red $(630 \mathrm{~nm})$ & $\begin{array}{l}\text { It induces melatonin } \\
\text { production, human } \\
\text { circadian system } \\
\text { photopigment, important at } \\
\text { bedtime }\end{array}$ & $\begin{array}{l}\text { Rhinitis treatment, wound } \\
\text { healing and } \\
\text { anti-inflammatory }{ }^{11}\end{array}$ & $\begin{array}{l}\text { It efficiently drives } \\
\text { photosynthesis and } \\
\text { photomorphogene-sis }^{12}\end{array}$ & $\begin{array}{l}\text { Algae growth, microalgae } \\
\text { cultivation, plant tissue } \\
\text { culture }^{11}\end{array}$ \\
\hline Green $(550 \mathrm{~nm})$ & $\begin{array}{l}\text { It is the second most } \\
\text { effective in suppressing } \\
\text { melatonin, helpful to reset } \\
\text { body clock }^{8}\end{array}$ & $\begin{array}{l}\text { Correct } \\
\text { hyperpigmentati-on, } \\
\text { eliminate skin spots }\end{array}$ & $\begin{array}{l}\text { Photosynthesis (less than } \\
\text { blue and red colors) }\end{array}$ & $\begin{array}{l}\text { Algae growth, bacteria and } \\
\text { microalgae cultivation }{ }^{11}\end{array}$ \\
\hline Blue $(480 \mathrm{~nm})$ & $\begin{array}{l}\text { The most effective in } \\
\text { suppressing melatonin. It } \\
\text { activates melanopsin, } \\
\text { responsible for alertness, } \\
\text { attention, and emotional } \\
\text { processes. Desirable during } \\
\text { the day but not at night }{ }^{9}\end{array}$ & $\begin{array}{l}\text { Seasonal Affective Disorder } \\
\text { (SAD), non-seasonal } \\
\text { depression and bipolar } \\
\text { disorder therapies }^{9}\end{array}$ & $\begin{array}{l}\text { It improves growth (dry } \\
\text { mass gain) and minimize } \\
\text { excessively elongated } \\
\text { stems }^{12}\end{array}$ & $\begin{array}{l}\text { Algae growth, astaxanthin } \\
\text { production }{ }^{11}\end{array}$ \\
\hline UV (250 nm) & $\begin{array}{l}\text { It is not well-understood, } \\
\text { since just } 2 \% \text { of UV } \\
\text { radiation survives after } \\
\text { filtration through the eye } \\
\text { lens }{ }^{10}\end{array}$ & $\begin{array}{l}\text { Disinfection, water } \\
\text { treatment }^{11}\end{array}$ & $\begin{array}{l}\text { Carotenoids and } \\
\text { polyamines induction, } \\
\text { damage to photosynthetic } \\
\text { apparatus }^{13}\end{array}$ & $\begin{array}{l}\text { Disinfection, water } \\
\text { treatment and purification }\end{array}$ \\
\hline
\end{tabular}

position processes) $)^{26-29}$ when compared to $\mathrm{Mn}(\mathrm{IV})$-doped fluorides or $\mathrm{Eu}(\mathrm{II})$-doped matrixes, due to the larger melting point of $\mathrm{Ba}_{2} \mathrm{SiO}_{4}$. Moreover, the $\mathrm{Ba}_{2} \mathrm{SiO}_{4}: \mathrm{Eu}(\mathrm{III})$ phosphor displays higher efficiency under excitation at $250 \mathrm{~nm}$, and the emission deviates to the visible, in particular, the radiative emission occurs at higher energies in the red spectral region $(\sim 610 \mathrm{~nm})$ compared with that of the $\mathrm{Mn}(\mathrm{IV})$-based systems, whose emission peaks $\sim 700 \mathrm{~nm}$, and partially lies within the NIR spectral region. ${ }^{30-32}$

In order to dose the UV radiation, the phosphor was dispersed in poly(methyl methacrylate) (PMMA) since it absorbs deep-UV radiation (Figure S1), acting as photo-selective coating to UV radiation through film thickness control. Moreover, PMMA is environmentally friendly, lightweight, low-cost and has high mechanical and optical resistance to UV radiation exposure. ${ }^{33}$ Therefore, inspired in the possibility of fabricating photo-selective films to be applied as coatings of multifunctional red-emitting LEDs, the $\mathrm{Ba}_{2} \mathrm{SiO}_{4}: \mathrm{Eu}(\mathrm{III})$ phosphor was prepared by sol-gel at distinct calcination times $(2 \mathrm{~h}$ and $10 \mathrm{~h})$ and dispersed in PMMA films with tunable thickness. Taking advantage of the $\mathrm{Eu}(\mathrm{III})$ photoluminescence properties, the intra- $4 f^{6}$ transitions were also used as a local probe to further investigate the role of $\mathrm{Eu}(\mathrm{III})$ doping on the optical features as function of the calcination time interval.

\section{Experimental}

Synthesis and processing.- The Eu(III) (4\%)-doped silicate phosphors were synthesized from an adapted sol-gel route by using $\mathrm{C}_{8} \mathrm{H}_{20} \mathrm{O}_{4} \mathrm{Si}$, (TEOS, Fluka, 99.9\%), $\mathrm{CH}_{3} \mathrm{COOH}$ (Acetic acid, VETEC, 97\%), $\mathrm{Eu}_{2} \mathrm{O}_{3}$ (Europium oxide, Aldrich, 99.99\%), $\mathrm{Gd}_{2} \mathrm{O}_{3}$ (Gadolinium oxide, Aldrich, 99.99\%), and $\mathrm{Ba}\left(\mathrm{CH}_{3} \mathrm{COO}\right)_{2}$ (Barium acetate, VETEC, $99.9 \%$ ) as starting reactants. ${ }^{34}$ The synthesis was designed in order to keep the overall charge. Since $\mathrm{Ba}(\mathrm{II})$ and $\mathrm{Eu}(\mathrm{III})$ have distinct charges, the following equation was considered: $2 n_{B a}+3 n_{E u}=4$, where $n_{B a}$ and $n_{E u}$ are the mol number of $\mathrm{Ba}(\mathrm{II})$ and $\mathrm{Eu}(\mathrm{III})$, respectively, yielding $\mathrm{Ba}_{1.88} \mathrm{Eu}_{0.08} \mathrm{SiO}_{4.00}$.

First, stoichiometric amounts of $\mathrm{Ba}\left(\mathrm{CH}_{3} \mathrm{COO}\right)_{2}(2.6494 \mathrm{~g})$ and $\mathrm{Eu}_{2} \mathrm{O}_{3}(0.0777 \mathrm{~g})$ were dissolved in $10 \mathrm{~mL}$ of acetic acid at $70^{\circ} \mathrm{C}$ to obtain $2.0000 \mathrm{~g}$ of the final product. Then TEOS in isopropyl alcohol solution $(8.83 \mathrm{~mL}, 0.55 \mathrm{~mol} / \mathrm{L})$ was added. The solution was kept under stirring for $4 \mathrm{~h}$ at $70^{\circ} \mathrm{C}$ until the gel formation. The gel was dried at $100^{\circ} \mathrm{C}$ for $2 \mathrm{~h}$, yielding the xerogel precursor. Finally, the xerogel was calcined in two different ways: (1) $450^{\circ} \mathrm{C}$ for $2 \mathrm{~h}$ with a heating ramp of $10^{\circ} \mathrm{C} / \mathrm{min}$ and $1100^{\circ} \mathrm{C}$ for $2 \mathrm{~h}$ with a heating ramp of $10^{\circ} \mathrm{C} / \mathrm{min}$ and (2) $450^{\circ} \mathrm{C}$ for $2 \mathrm{~h}$ with a heating ramp of $10^{\circ} \mathrm{C} / \mathrm{min}$, $1000^{\circ} \mathrm{C}$ for $2 \mathrm{~h}$ with a heating ramp of $10^{\circ} \mathrm{C} / \mathrm{min}$ and $1100^{\circ} \mathrm{C}$ for $10 \mathrm{~h}$ with a heating ramp of $10^{\circ} \mathrm{C} / \mathrm{min}$. After each annealing step, samples were brought back to room temperature, without reground.

To support the assignments of the luminescent features, $\mathrm{Ba}_{1.88} \mathrm{Gd}_{0.08} \mathrm{SiO}_{4.00}$ sample was synthesized in the same way of $\mathrm{Ba}_{1.88} \mathrm{Eu}_{0.08} \mathrm{~S}_{4.00}$, replacing $\mathrm{Eu}_{2} \mathrm{O}_{3}$ by $\mathrm{Gd}_{2} \mathrm{O}_{3}$. The samples will be hereafter designated as $\mathrm{Ln}-\mathrm{X}$, where $\mathrm{Ln}=\mathrm{Eu}$ or $\mathrm{Gd}$ and $\mathrm{X}=2 \mathrm{~h}$ and $10 \mathrm{~h}$ indicates the thermal treatment time at $1100^{\circ} \mathrm{C}$.

PMMA-based film.-The PMMA matrix was produced mixing methyl methacrylate $(10 \mathrm{~g})$ with benzoyl peroxide $(0.6 \mathrm{~g})$ in a glass vial. The mixture was heated at $80-90^{\circ} \mathrm{C}$ for $30 \mathrm{~min}$ and then, placed in an oven at $40^{\circ} \mathrm{C}$ until the complete polymerization. The films containing the $\mathrm{Ba}_{1.88} \mathrm{Eu}_{0.08} \mathrm{~S}_{4.00}$ phosphor were deposited by dropcasting. First, PMMA (0.6069 g) was dissolved in dichloromethane $(10 \mathrm{~mL})$, and $1.7 \mathrm{~mL}$ of this solution was deposited in a $2.2 \times$ $2.2 \mathrm{~cm}^{2}$ glass substrate (thickness of $0.1 \mathrm{~cm}$ ) forming the undoped PMMA film (0.1042 g). This PMMA weight was considered as the reference of $100 \mathrm{wt} \%$. Then, stoichiometric amounts of Eu-2h and PMMA/dichloromethane solution were mixed to produce films with tunable PMMA:Eu2h weight proportions, namely $1: \mathrm{M}$, where $\mathrm{M}=$ $0.25,1.00,2.00,3.00$ and $4.00(20,50,66,75$ and $80 \mathrm{wt} \%$, respectively). These suspensions were deposited in a $2.2 \times 2.2 \mathrm{~cm}^{2}$ glass substrate (thickness of $0.1 \mathrm{~cm}$ ) and dried at $300 \mathrm{~K}$ for $24 \mathrm{~h}$. Finally, the optimized deposition condition (1:2) was used to fabricate the film using the Eu-10h phosphor. The films will be hereafter designated as PMMA:MEu-X, where $\mathrm{M}=0.25,1,2,3$ and 4 and $\mathrm{X}=2 \mathrm{~h}$ or $10 \mathrm{~h}$.

Structural and optical characterizations.-X-ray diffraction $(X R D)$.- The diffractograms were acquired in a PANalytical Empyrean diffractometer at $300 \mathrm{~K}$, from $9.0000^{\circ}$ to $99.9000^{\circ}$, step size of $0.0260^{\circ}$, scan step time of $67.0650 \mathrm{~s}$ using $\mathrm{CuK}_{\alpha}$ radiation (1.54060 ̊). Crystalline structure and phase composition of Eu-2h and $\mathrm{Eu}-10 \mathrm{~h}$ were refined according to the Rietveld method (Table S1, Supporting Information).

Optical microscopy.-The thickness of the films was measured through optical microscopy using an Olympus BX51 bright field mi- 

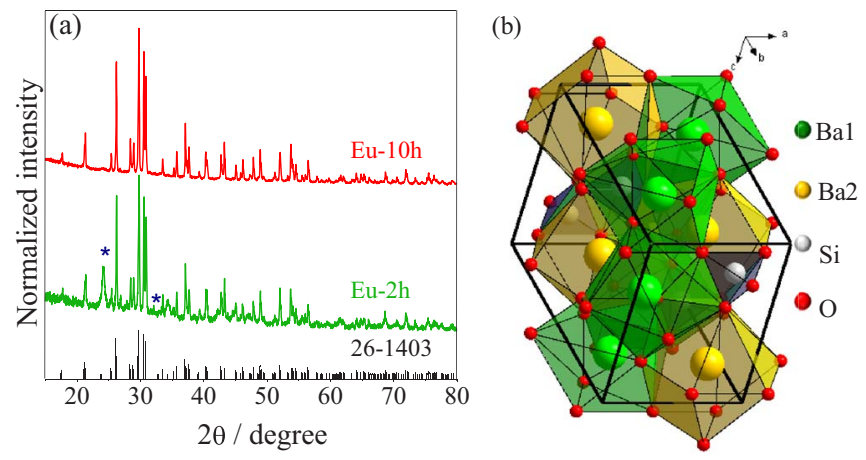

Figure 2. (a) Powder XRD of the Eu(III)-based phosphors calcined for $2 \mathrm{~h}$ and $10 \mathrm{~h}$ compared to the JCPDS-26-1403 $\mathrm{Ba}_{2} \mathrm{SiO}_{4}$ pattern (the asterisks represent the peaks assigned to the $\mathrm{BaSiO}_{3}$ spurious phase). (b) $\mathrm{Ba}_{2} \mathrm{SiO}_{4}$ unit cell representation based on the CIF file available on Inorganic Crystal Structure Database (ICSD); $\mathrm{Ba} 1$ and $\mathrm{Ba} 2$ are the notation for sites with $\mathrm{CN} 9$ and 10, respectively.

croscope $(10 \times$ objective $)$, in the reflection mode, equipped with a hyperspectral imaging system (CytoViva Inc., Auburn, AL). The system integrates an optical imaging CCD camera (QImaging Retiga 4000R), a visible/near-infrared hyperspectral camera (Cytoviva), a motorized stage and a halogen light source (Fiber-lite, DC-950).

Absorption spectroscopy.-UV/visible absorption spectra were recorded using a Lambda 950 dual-beam spectrometer (Perkin-Elmer) from $200 \mathrm{~nm}$ to $800 \mathrm{~nm}$, step size of $1 \mathrm{~nm}$.

Photoluminescence spectroscopy.-The spectra were recorded at 14 and $300 \mathrm{~K}$ with a modular double-grating excitation spectrofluorimeter with a TRIAX 320 emission monochromator (Fluorolog3, Horiba Scientific) coupled to a R928 Hamamatsu photomultiplier. The reciprocal Linear Dispersion of the diffraction gratings is $2.66 \mathrm{~nm} \cdot \mathrm{mm}^{-1}$, and for the high-resolution emission spectra $(14 \mathrm{~K})$, the excitation and emission slits were placed at $2 \times 10^{6}$ and $3 \times 10^{4} \mathrm{~nm}$, respectively, which results in a spectral resolution of $0.079 \mathrm{~nm}$. Lifetime measurements for the $\mathrm{Eu}(\mathrm{III})$-doped samples were carried out at $14 \mathrm{~K}$ by using a pulsed Xe arc lamp $(6 \mathrm{~mJ} /$ pulse $)$ coupled to a Kratos GM-252 monochromator and a Spex 1934 C phosphorimeter. The widths of the slits of the excitation and emission monochromator were placed at $2 \times 10^{6}$ and $1 \times 10^{5} \mathrm{~nm}$, respectively, resulting in a spectral resolution of $0.27 \mathrm{~nm}$. The emission color coordinates $(x, y)$ were calculated accordingly to the 1931 Commission Internationale de L'Éclairage (CIE) chromaticity standards defined for the $2^{\circ}$ observer. ${ }^{35}$

Luminous flux.-The luminous flux was measured using an integrating sphere ISP 150L-131 from Instrument Systems with internal diameter of $150 \mathrm{~mm}\left(\mathrm{BaSO}_{4}\right.$ coating) and coupled to an array spectrometer MAS 40 from Instrument Systems. A lamp emitting at $254 \mathrm{~nm}$ and optical power of $3.2 \pm 0.1 \times 10^{-3} \mathrm{~W}$ was used as excitation source. The accuracy is $5 \%$, accordingly to the manufacturer.

Absolute emission quantum yield.-The absolute emission quantum yields were measured at $300 \mathrm{~K}$ using a system (Quantaurus-QY Plus C13534, Hamamatsu) with a $150 \mathrm{~W}$ xenon lamp coupled to a monochromator for wavelength discrimination, an integrating sphere as the sample chamber, and a multichannel analyzer for signal detection. The accuracy is $10 \%$, accordingly to the manufacturer.

\section{Results and Discussion}

Eu(III)-doped $\mathrm{Ba}_{2} \mathrm{SiO}_{4}$ phosphor.-The local structure was characterized by powder XRD measurements, Figure 2. For the samples calcined during $2 \mathrm{~h}(\mathrm{Eu}-2 \mathrm{~h})$, the diffraction pattern is indexed to the or- thorhombic $\mathrm{Ba}_{2} \mathrm{SiO}_{4}$ phase (JCPDS 26-1403, number 62, $P_{\text {nma }}$ space group) as the major phase (82.9 wt\%) and two other secondary ones identified as $\beta-\mathrm{BaSiO}_{3}$ (JCPDS 26-1402, number 19, $\mathrm{P} 2{ }_{1} 2_{1} 2_{1}$ space group) (16.8 wt \%) and $\mathrm{SiO}_{2}$ (quartz, JCPDS 46-1045, number 152, $\mathrm{P} 3_{1} 21$ space group) $(0.3 \mathrm{wt} \%)$. No diffraction peaks indexed to the $\mathrm{Eu}_{2} \mathrm{O}_{3}$ phase were observed. At longer calcination time, the diffractogram of Eu-10h only reveals the orthorhombic $\mathrm{Ba}_{2} \mathrm{SiO}_{4}$ phase (JCPDS 26-1403), pointing out that the increase of the calcination time is crucial to decrease the quantity of spurious phases.

According to the phase diagram of the $\mathrm{BaO}-\mathrm{SiO}_{2}$ binary mixture, ${ }^{36}$ the suitable molar proportion of $\mathrm{Si}$ in relation to $\mathrm{Ba}$ to form $\mathrm{Ba}_{2} \mathrm{SiO}_{4}$ without spurious phases is $33.3 \%$, under heating of $1100^{\circ} \mathrm{C}$. However, due to the doping with the activator ion, to compensate the charge difference between $\mathrm{Eu}(\mathrm{III})$ and $\mathrm{Ba}$ (II), the Si molar proportion is $35 \%$, enabling the formation of low amounts of $\mathrm{BaSiO}_{3}$. Because of this non-stoichiometry, it will be always possible to find $\mathrm{BaSiO}_{3}$ in the phosphor composition regardless of the calcination condition.

The structural parameters (Table S1) are in accordance with those previously found in the literature for $\mathrm{Ba}_{2} \mathrm{SiO}_{4}{ }^{37}$ and $\mathrm{BaSiO}_{3}{ }^{38}$ matrixes. The $\mathrm{Si}(\mathrm{IV})$ ions are in tetrahedral coordination sites with oxygen ions in the tetrahedra vertices and ionic radius of $40 \mathrm{pm}$. The Ba(II) occupies two crystallographic positions with analogous occurrence in the $\mathrm{Ba}_{2} \mathrm{SiO}_{4}$ structure, Figure $2 \mathrm{~b}$. One position with coordination number $\mathrm{CN}=10$ and ionic radius of $166 \mathrm{pm}$ forms a chain along the c-axis and other structurally distorted with $\mathrm{CN}=9$ and ionic radius of $161 \mathrm{pm}$ establishes chains along the b-axis.

In turn, in the $\mathrm{BaSiO}_{3}$ lattice, the $\mathrm{Ba}(\mathrm{II})$ occupies a single site with $\mathrm{CN}=8$ and ionic radius of $142 \mathrm{pm}$. Eu(III) has ionic radius of $131 \mathrm{pm}$ $(\mathrm{CN}=10), 126 \mathrm{pm}(\mathrm{CN}=9)$, and $107 \mathrm{pm}(\mathrm{CN}=8)$ and even that the rare-earth ionic radius is smaller than that of $\mathrm{Ba}(\mathrm{II})$, the substitution is favored since the ionic radii difference between both is lower than $30 \% .{ }^{39}$ Due to the large difference between the ionic radii of Eu(III) and $\mathrm{Si}(\mathrm{IV})$, the replacement of $\mathrm{Si}(\mathrm{IV})$ by $\mathrm{Eu}(\mathrm{III})$ is unlikely to take place.

Due to the charge compensation mechanism considered in the $\mathrm{Eu}(\mathrm{III})$-based phosphor synthesis, structural defects arise in the lattice since two $\mathrm{Eu}(\mathrm{III})$ replace three $\mathrm{Ba}(\mathrm{II})$, as previously noticed. ${ }^{26} \mathrm{As}$ consequence, a doubled negative Ba-related vacancy $\left(V_{B a}^{\prime \prime}\right)$ defect and two positive defects arising from $\mathrm{Eu}(\mathrm{III})$ occupying $\mathrm{Ba}(\mathrm{II})$ sites $\left(E u_{B a}^{\bullet}\right)$ are generated, as represented in Eq. 1.

$$
3 B a^{2+}+2 E u^{3+} \rightarrow V_{B a}^{\prime \prime}+2 E u_{B a}^{\bullet}
$$

The $V_{B a}^{\prime \prime}$ leads to a local expansion in its environment due to the oxygen negative charge repulsion, and in the $E u_{B a}^{\bullet}$ sites, there is a local compression due to the positive charge increase. This compression is also favored because $\mathrm{Eu}(\mathrm{III})$ ionic radius is smaller than that of $\mathrm{Ba}(\mathrm{II})$. Furthermore, due to the non-stoichiometry of the synthesis, distorted $\mathrm{Eu}(\mathrm{III})$ or $\mathrm{Ba}(\mathrm{II})$ sites (local sites named as $\mathrm{Eu}_{\mathrm{D} 1-\mathrm{D} 3}$ ) are formed, leading to the appearance of $\mathrm{Eu}(\mathrm{III})$ sites different from that typically expected by the replacement of $\mathrm{Ba}(\mathrm{II})$ in the $\mathrm{Ba}_{2} \mathrm{SiO}_{4}$ and $\mathrm{BaSiO}_{3}$ structures (local sites named as $\left.\mathrm{Eu}_{1-3}\right){ }^{40}$ In this context, considering the XRD data, we expect that Eu(III) occupies six nonequivalent sites $\left(\mathrm{Eu}_{1-3}\right.$ and $\left.\mathrm{Eu}_{\mathrm{D} 1-\mathrm{D} 3}\right)$ in $\mathrm{Eu}-2 \mathrm{~h}$ and four non-equivalent sites $\left(\mathrm{Eu}_{1-2}\right.$ and $\left.\mathrm{Eu}_{\mathrm{D} 1-\mathrm{D} 2}\right)$ in $\mathrm{Eu}-10 \mathrm{~h}$.

Under UV irradiation, all the samples display an intense red emission color, as illustrated in Figure 3a. To infer the preferential excitation optical paths, excitation spectra were monitored at $610.4 \mathrm{~nm}$ $\left({ }^{5} \mathrm{D}_{0} \rightarrow{ }^{7} \mathrm{~F}_{2}\right.$ transition), Figure $3 \mathrm{~b}$, exhibiting a broad excitation band in the deep-UV region assigned to the $\mathrm{Eu}^{3+} \rightarrow \mathrm{O}^{2-}$ charge transfer band $(\mathrm{CTB})^{41}$ and narrow lines attributed to the Laporte's forbidden Eu(III) $f-f$ transitions. The main excitation path at $\sim 250 \mathrm{~nm}$ is fundamental to use these materials as coatings of deep-UV emitting LEDs. We notice that $\mathrm{Mn}(\mathrm{IV})$ or $\mathrm{Eu}(\mathrm{II})$-based red-emitting phosphors typically feature weak absorption in this spectral region. ${ }^{30-32}$

The phosphor emission spectra under deep-UV excitation reveal a series of $\mathrm{Eu}(\mathrm{III})$ transitions from the ${ }^{5} \mathrm{D}_{0}$ excited level to the ${ }^{7} \mathrm{~F}_{\mathrm{J}}$ $(\mathrm{J}=0-4)$ levels, Figure 3c. The high number of components for each transition, in particular, the presence of more than one com- 
(a)

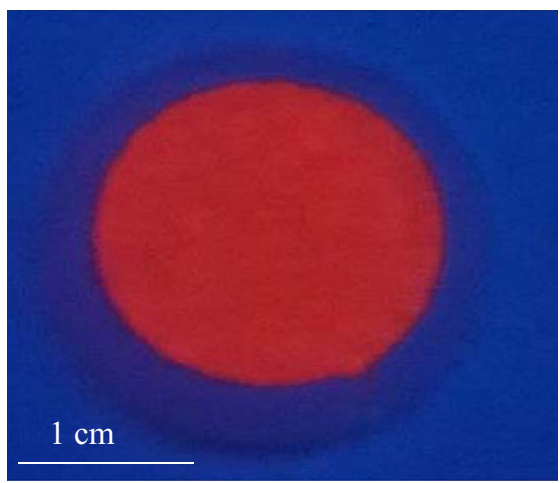

(c)

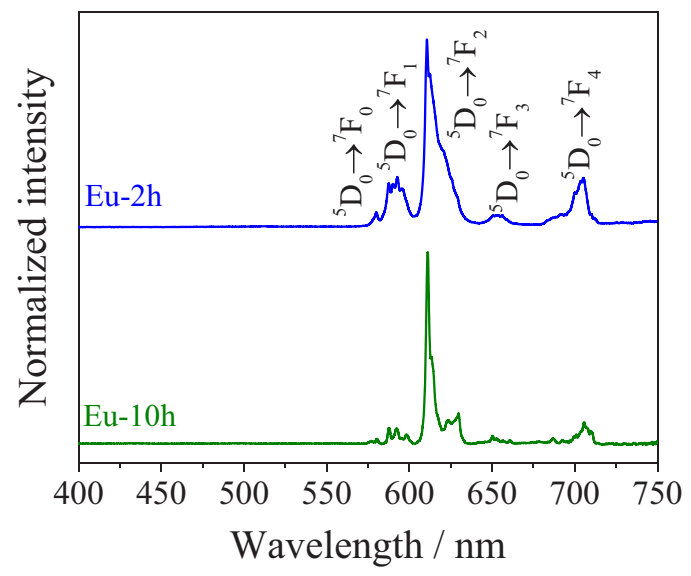

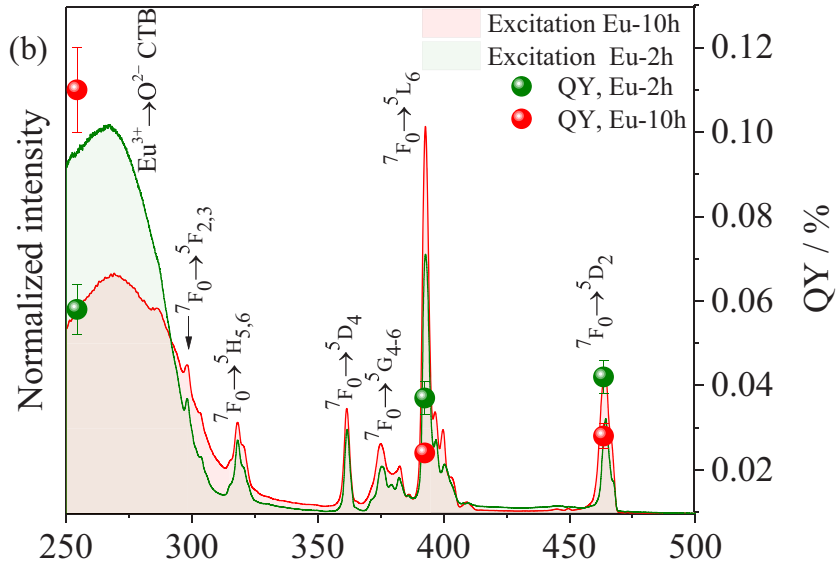

(d)

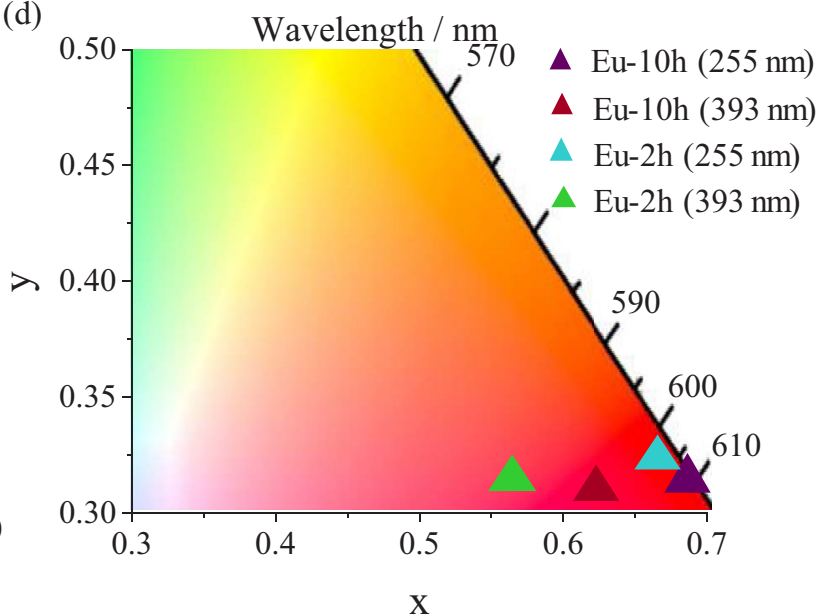

Figure 3. (a) Photo of the Eu-10 h sample under UV radiation $(255 \mathrm{~nm}$ ). (b) Absolute emission quantum yield ( $q$ ) of the Eu(III)-based phosphors compared to the excitation spectra. (c) Emission spectra (300 K) excited at $255 \mathrm{~nm}$ of the Eu(III)-based phosphors. (d) CIE chromaticity diagram of Eu-2h and Eu-10h.

ponent for the non-degenerated ${ }^{5} \mathrm{D}_{0} \rightarrow{ }^{7} \mathrm{~F}_{0}$ transition, readily indicates that $\mathrm{Eu}(\mathrm{III})$ is inserted in more than one non-equivalent local coordination site, as detailed below. The red emission was quantified by the calculation of CIE color coordinates, Figure 3d. For Eu$2 \mathrm{~h} / \mathrm{Eu}-10 \mathrm{~h}$, the $(\mathrm{x}, \mathrm{y})$ color coordinates are within the red spectral region, $(0.659 ; 0.324) /(0.686 ; 0.315)$ and $(0.569 ; 0.316) /(0.622 ; 0.310)$ under excitation at $255 \mathrm{~nm}$ and $393 \mathrm{~nm}$, respectively.

To further discuss the $\mathrm{Eu}(\mathrm{III})$-local environments as function of the heat-treatment, low-temperature high-resolution emission spectra under $255 \mathrm{~nm}$ and $393 \mathrm{~nm}$ excitation were collected in the ${ }^{5} \mathrm{D}_{0} \rightarrow{ }^{7} \mathrm{~F}_{0}$ transition range, Figure $4 \mathrm{a}$. The ${ }^{5} \mathrm{D}_{0} \rightarrow{ }^{7} \mathrm{~F}_{0}$ transition exhibits at least five and eight components under excitation at 255 and $393 \mathrm{~nm}$ respectively, suggesting that $\mathrm{Eu}(\mathrm{III})$ is, at least, inserted in 8 non-equivalent local sites without inversion center. In accordance, we note that the ${ }^{5} \mathrm{D}_{0} \rightarrow{ }^{7} \mathrm{~F}_{1}$ transition, that occurs by a magnetic dipole mechanism and exhibits up to three components per each Eu(III) non-equivalent site, shows at least eight and eleven well-defined components at 255 and $393 \mathrm{~nm}$ excitation, respectively, Figure $4 \mathrm{~b}$. Likewise, the ${ }^{5} \mathrm{D}_{0} \rightarrow{ }^{7} \mathrm{~F}_{2}$ transition has a maximum of five components per each $\mathrm{Eu}(\mathrm{III})$ nonequivalent site. In both $\mathrm{Eu}-2 \mathrm{~h}$ and $\mathrm{Eu}-10 \mathrm{~h}$, at least ten components are noticed in the emission spectra, Figure 4c, under both 255 and $393 \mathrm{~nm}$ excitation.

Focusing our attention into the eight components found for the ${ }^{5} \mathrm{D}_{0} \rightarrow{ }^{7} \mathrm{~F}_{0}$ transition, the components at $580.1 \mathrm{~nm}$ and $508.6 \mathrm{~nm}$ are tentatively assigned to the $\mathrm{Eu}_{1}$ and $\mathrm{Eu}_{2}$ local sites, respectively, Table II and Figure 4d, based on the changes in their intensities with

Table II. Energy $\left(\mathrm{cm}^{-1}\right)$ of the components for the ${ }^{5} \mathrm{D}_{0} \rightarrow{ }^{7} \mathrm{~F}_{0}$ transitions and ${ }^{5} \mathrm{D}_{0}$ lifetime ( $\tau$ ) values of each component excited at $393 \mathrm{~nm}(14 \mathrm{~K})$ for Eu-2h, Eu-10h and PMMA:Eu-10h.

$\tau / \mathrm{ms}$

\begin{tabular}{|c|c|c|c|c|c|}
\hline Notation for Eu ions & Wavelength $/ \pm 0.08 \mathrm{~nm}$ & Energy/ $\pm 3 \mathrm{~cm}^{-1}$ & $\mathrm{Eu}-2 \mathrm{~h}$ & Eu-10h & PMMA:Eu-10h \\
\hline $\mathrm{Eu}_{1}$ & 578.22 & 17295 & $1.60 \pm 0.03$ & $1.73 \pm 0.03$ & $0.903 \pm 0.015$ \\
\hline $\mathrm{Eu}_{2}$ & 579.56 & 17256 & $1.19 \pm 0.04$ & $1.50 \pm 0.02$ & $0.846 \pm 0.014$ \\
\hline $\mathrm{Eu}_{3}$ & 580.12 & 17238 & $1.36 \pm 0.03$ & $0.79 \pm 0.02$ & $0.495 \pm 0.032$ \\
\hline $\mathrm{Eu}_{\mathrm{D} 1}$ & 580.62 & 17223 & $1.22 \pm 0.03$ & $1.13 \pm 0.01$ & - \\
\hline $\mathrm{Eu}_{\mathrm{D} 2}$ & 581.54 & 17196 & $0.60 \pm 0.02$ & $0.66 \pm 0.03$ & - \\
\hline $\mathrm{Eu}_{\mathrm{D} 3}$ & 582.35 & 17173 & $0.28 \pm 0.02$ & $0.11 \pm 0.02$ & $0.016 \pm 0.001$ \\
\hline $\mathrm{Eu}_{\mathrm{A} 1}$ & 572.64 & 17464 & $0.77 \pm 0.02$ & $0.68 \pm 0.01$ & $0.628 \pm 0.009$ \\
\hline $\mathrm{Eu}_{\mathrm{A} 2}$ & 573.13 & 17448 & $0.69 \pm 0.01$ & - & - \\
\hline
\end{tabular}



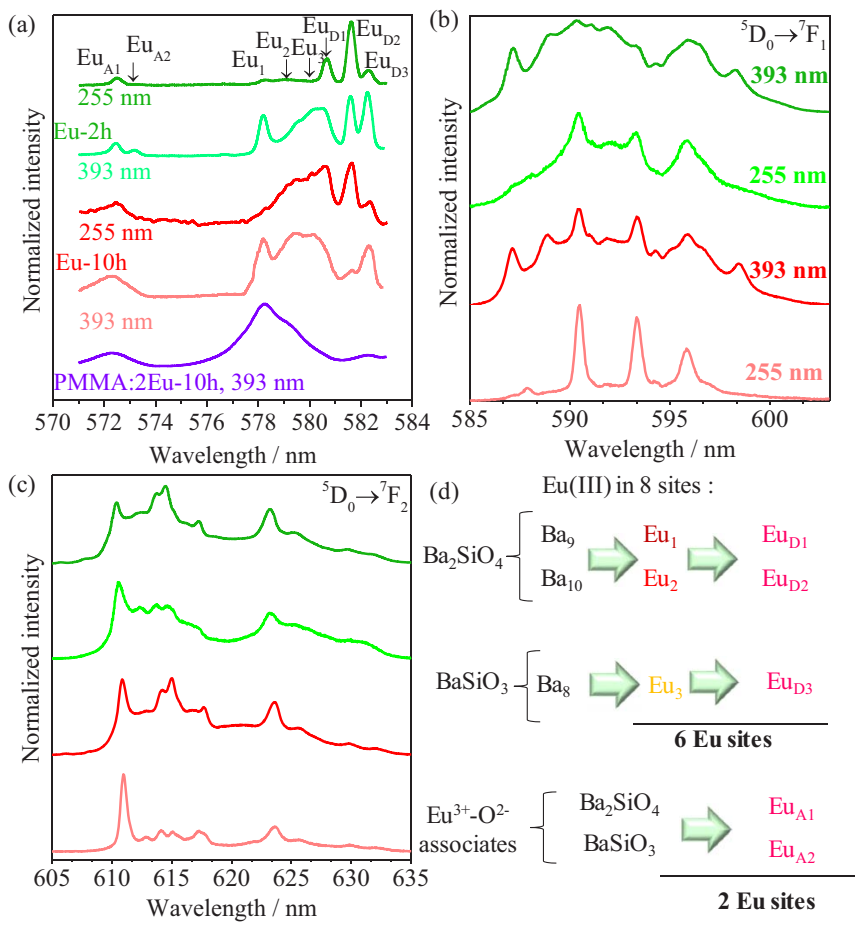

$\mathrm{Eu}(\mathrm{III})$ in 8 sites

Figure 4. High-resolution emission spectra (14 K) excited at different excitation wavelength for Eu(III)-based phosphors and the PMMA:2Eu-10h film in the (a) ${ }^{5} \mathrm{D}_{0} \rightarrow{ }^{7} \mathrm{~F}_{0}$, (b) ${ }^{5} \mathrm{D}_{0} \rightarrow{ }^{7} \mathrm{~F}_{1}$, and (c) ${ }^{5} \mathrm{D}_{0} \rightarrow{ }^{7} \mathrm{~F}_{2}$ transition region. (d) Representation of $\mathrm{Eu}$ (III) local sites $\left(\mathrm{Eu}_{1-3}, \mathrm{Eu}_{\mathrm{D} 1-3}\right.$ and $\left.\mathrm{Eu}_{\mathrm{A} 1,2}\right)$ in the $\mathrm{Eu}$ (III)-doped phosphors.

the increase of the calcination time. The XRD data establishes six and four non-equivalent ${ }^{5} \mathrm{D}_{0} \rightarrow{ }^{7} \mathrm{~F}_{0}$ components for $\mathrm{Eu}-2 \mathrm{~h}$ and Eu-10h, respectively. However, both samples show the same number of ${ }^{5} \mathrm{D}_{0} \rightarrow{ }^{7} \mathrm{~F}_{0}$ transitions with the same energy, whose relative intensity variation indicates that there are some $\mathrm{BaSiO}_{3}$ traces in the sample composition, even for Eu-10h, evidencing the greater sensitivity limit of the spectroscopic technique in detriment of XRD. When the calcination time increases from $2 \mathrm{~h}$ to $10 \mathrm{~h}$, the ${ }^{5} \mathrm{D}_{0} \rightarrow{ }^{7} \mathrm{~F}_{0}$ components at $580.1 \mathrm{~nm}$ $\left(\mathrm{Eu}_{3}\right), 580.6 \mathrm{~nm}\left(\mathrm{Eu}_{\mathrm{D} 1}\right), 581.5 \mathrm{~nm}\left(\mathrm{Eu}_{\mathrm{D} 2}\right)$ and $582.3 \mathrm{~nm}\left(\mathrm{Eu}_{\mathrm{D} 3}\right)$ have their relative intensity decreased compared to the other components, Figure $4 \mathrm{a}$. Besides that, the relative intensity of the components at $578.2 \mathrm{~nm}\left(\mathrm{Eu}_{1}\right)$ and $579.5 \mathrm{~nm}\left(\mathrm{Eu}_{2}\right)$ increases. These observations suggest that the components at $580.1 \mathrm{~nm}\left(\mathrm{Eu}_{3}\right), 580.6 \mathrm{~nm}\left(\mathrm{Eu}_{\mathrm{D} 1}\right)$, $581.5 \mathrm{~nm}\left(\mathrm{Eu}_{\mathrm{D} 2}\right)$ and $582.3 \mathrm{~nm}\left(\mathrm{Eu}_{\mathrm{D} 3}\right)$ correspond to the $\mathrm{BaSiO}_{3} \mathrm{spu}-$ rious phase or defect sites, and for the other 2 components, they arise from the $\mathrm{Ba}_{2} \mathrm{SiO}_{4}$ phase since the fraction of the $\mathrm{BaSiO}_{3}$ phase decreases as the calcination time increases, according to the XRD data.

In order to further assign the remaining ${ }^{5} \mathrm{D}_{0} \rightarrow{ }^{7} \mathrm{~F}_{0}$ transition components, site-selective excitation spectra were monitored around each ${ }^{5} \mathrm{D}_{0} \rightarrow{ }^{7} \mathrm{~F}_{0}$ transition, around $578.2 \mathrm{~nm}\left(\mathrm{Eu}_{1}\right), 579.6 \mathrm{~nm}\left(\mathrm{Eu}_{2}\right), 580.1 \mathrm{~nm}$ $\left(\mathrm{Eu}_{3}\right), 580.6 \mathrm{~nm}\left(\mathrm{Eu}_{\mathrm{D} 1}\right), 581.5 \mathrm{~nm}\left(\mathrm{Eu}_{\mathrm{D} 2}\right)$, and $582.3 \mathrm{~nm}\left(\mathrm{Eu}_{\mathrm{D} 3}\right)$, Figure 5. The excitation spectra are similar, indicating analogous ${ }^{5} \mathrm{D}_{0}$ population paths being tentatively ascribed to $\mathrm{Eu}(\mathrm{III})$ located within the $\mathrm{Ba}_{2} \mathrm{SiO}_{4}$ or $\mathrm{BaSiO}_{3}$ matrices. For these components, it is also possible to distinguish two different bands in the excitation spectra at $255 \mathrm{~nm}$ and $275 \mathrm{~nm}$ assigned to the CTB arising from Eu replacing Ba sites in the $\mathrm{Ba}_{2} \mathrm{SiO}_{4}$ or $\mathrm{BaSiO}_{3}$ matrices (CTB1).

It is feasible to assign the CTB1 band $(\sim 275 \mathrm{~nm})$ to the $\mathrm{Eu}_{\mathrm{D} 1-3}$ sites since the $\mathrm{CN}$ of these sites is lower than the $\mathrm{Eu}_{1-3}$ ones ${ }^{42}$ and it is wellknown that a decrease in $\mathrm{CN}$ leads to a decrease of the CTB energy. ${ }^{43}$ This premise confirms that the sites at $578.2 \mathrm{~nm}\left(\mathrm{Eu}_{1}\right), 579.5 \mathrm{~nm}\left(\mathrm{Eu}_{2}\right)$ and $580.1 \mathrm{~nm}\left(\mathrm{Eu}_{3}\right)$ come from the $\mathrm{Ba}_{2} \mathrm{SiO}_{4}$ or $\mathrm{BaSiO}_{3}$ structures since we cannot notice them in the emission spectra under $255 \mathrm{~nm}$ excitation for Eu-2h, Figure 4a. However, they are noticed for Eu-10h, where the concentration of $\mathrm{Eu}_{1-3}$ local sites is larger than that in $\mathrm{Eu}-2 \mathrm{~h}$.

The excitation spectra monitored around $572.6 \mathrm{~nm}\left(\mathrm{Eu}_{\mathrm{A} 1}\right)$ and $573.1 \mathrm{~nm}\left(\mathrm{Eu}_{\mathrm{A} 2}\right)$, Figure 5, reveals an additional broadband peaking at $\sim 330 \mathrm{~nm}$ (hereafter designated as CTB2), similar to that found in the excitation spectra of $\mathrm{Eu}^{3+}-\mathrm{O}^{2-}$ associates, ${ }^{44}$ suggesting that in the $\mathrm{Eu}_{\mathrm{A} 1}$ and $\mathrm{Eu}_{\mathrm{A} 2}$ sites, $\mathrm{Eu}$ (III) is bonded to oxygen ions that do not belong to the silicate network. The formation of the $\mathrm{Eu}^{3+}-\mathrm{O}^{2-}$ associates is usually related to a charge compensation mechanism, but they may also be formed when the matrix is rather loosely packed or contain chains formed by M-O polyhedral with unfilled spaces that may locate oxygen ions in their interstices. ${ }^{45}$ In the present case, whereas the $\mathrm{Ba}_{2} \mathrm{SiO}_{4}$ and $\mathrm{BaSiO}_{3}$ matrices contain $\mathrm{Ba}-\mathrm{O}$ polyhedral chains with unfilled spaces, it is feasible to assume the presence of $\mathrm{Eu}^{3+}$ $\mathrm{O}^{2-}$ associates $\left(\mathrm{Eu}_{\mathrm{A} 1}\right.$ and $\left.\mathrm{Eu}_{\mathrm{A} 2}\right)$. Under excitation at $330 \mathrm{~nm}(\mathrm{CTB} 2)$, the ${ }^{5} \mathrm{D}_{0} \rightarrow{ }^{7} \mathrm{~F}_{0}$ transition at $572.6 \mathrm{~nm}\left(\mathrm{Eu}_{\mathrm{A} 1}\right)$ dominates the emission profile, characteristic of the $\mathrm{Eu}^{3+}-\mathrm{O}^{2-}$ associate emission, Figure 6. Moreover, two ${ }^{5} \mathrm{D}_{0} \rightarrow{ }^{7} \mathrm{~F}_{2}$ components $(621.8 \mathrm{~nm}$ and $623.9 \mathrm{~nm})$ are only noticed under CTB2 excitation.

To further discuss the nature of the bands at $255 \mathrm{~nm}, 275 \mathrm{~nm}$ and $330 \mathrm{~nm}$ in the excitation spectra (Figure 5), the diffuse reflectance spectra of the isostructural Gd-2h sample were measured. The energy of the Gd(III) excited levels is much higher than the typical energy of defects-related bands, inhibiting any energy transfer process, and therefore the spectrum of $\mathrm{Gd}-2 \mathrm{~h}$ is free from any CTB contribution. ${ }^{46}$

Like the excitation spectra in Figure 5, the diffuse reflectance spectrum of Eu-2h, Figure 7a, shows three broad bands and a series of low-intensity lines assigned to the Eu(III) $f-f$ transitions. The high energy band $(\sim 217 \mathrm{~nm})$ is attributed to transitions from the valence band to the conduction band of the matrix. ${ }^{26}$ Regarding the two bands at $\sim 250 \mathrm{~nm}$ and $\sim 320 \mathrm{~nm}$, the spectrum of the Eu- $2 \mathrm{~h}$ was compared with that of the analogous Gd-2h. Interestingly, the arithmetical difference between them, Figure $7 \mathrm{~b}$, reveals two bands at $\sim 250 \mathrm{~nm}$ (CTB1) and $\sim 320 \mathrm{~nm}$ (CTB2) confirming that they arise from CTB processes between the matrix and $\mathrm{Eu}(\mathrm{III})$, supporting the assignments in the excitation spectra, Figure 5. The band at $250 \mathrm{~nm}$ (CTB1) displays a component at $275 \mathrm{~nm}$, also discerned in the excitation spectra, Figure 5.

To further examine the Eu(III) local sites, selective emission decay curves (Figures S2 and S3) were monitored around each of the eight ${ }^{5} \mathrm{D}_{0} \rightarrow{ }^{7} \mathrm{~F}_{0}$ components at $14 \mathrm{~K}$ since, at $300 \mathrm{~K}$, it is not possible to distinguish all the eight ${ }^{5} \mathrm{D}_{0} \rightarrow{ }^{7} \mathrm{~F}_{0}$ components. All the decay curves reveal a single exponential behavior in good agreement with experimental site-selective conditions. From the data best fit, the ${ }^{5} \mathrm{D}_{0}$ lifetime $(\tau)$ values were calculated for each Eu(III) local environment, Table II. The ${ }^{5} \mathrm{D}_{0}$ lifetime values for $\mathrm{Eu}_{1-3}$ local sites are similar to those found in other silicate-based matrices, ${ }^{47,48}$ and for the $\mathrm{Eu}_{\mathrm{A} 1}$ and $\mathrm{Eu}_{\mathrm{A} 2}$, they are faster, in accordance with the $\mathrm{Eu}^{3+}-\mathrm{O}^{2-}$ associate assignment. ${ }^{44}$

The distinct values found for the ${ }^{5} \mathrm{D}_{0}$ lifetime at $14 \mathrm{~K}(\mathrm{Eu}-2 \mathrm{~h}) \mathrm{com}-$ pared to those ones at $300 \mathrm{~K}$ give further evidence for the proposed assignment of the eight Eu(III) local sites. However, it was only possible to estimate the ${ }^{5} \mathrm{D}_{0}$ lifetime value $(300 \mathrm{~K})$ for the component at $578.2 \mathrm{~nm}\left(\mathrm{Eu}_{1}\right)$ through a biexponential fit, Figure $\mathrm{S} 4$, due to the superposition of the $\mathrm{Eu}_{1}$ and $\mathrm{Eu}_{2}$ components at $300 \mathrm{~K}$; therefore, the values obtained through the biexponential fit may be associated to the $\mathrm{Eu}_{1}$ and $\mathrm{Eu}_{2}$ local sites. The ${ }^{5} \mathrm{D}_{0}$ lifetime values at $300 \mathrm{~K}$ of the $\mathrm{Eu}_{1}$ and $\mathrm{Eu}_{2}$ local sites are to be found as $1.55 \pm 0.04 \mathrm{~ms}$ and $0.0568 \pm 0.005 \mathrm{~ms}$ and they are shorter than the values found at $14 \mathrm{~K}$, Table II. The $\mathrm{Eu}_{2}$ local site displays shorter ${ }^{5} \mathrm{D}_{0}$ lifetime than $\mathrm{Eu}_{1}$, indicating that the $\mathrm{Eu}_{2}$ site is more influenced by thermally activated non-radiative pathways. Attending to the fact that the experimental transition probability may be expressed as $\tau^{-1}=\tau_{n r}{ }^{-1}+\tau_{r}{ }^{-1}$, where $\tau_{n r}$ and $\tau_{r}$ represent the non-radiative and radiative lifetimes, respectively, and that at $14 \mathrm{~K}$ $\tau^{-1} \sim \tau_{r}{ }^{-1}$, the increase in $\tau$ as the temperature decreases suggests the presence of competing thermally activated non-radiative mechanisms.

$\mathrm{Eu}(\mathrm{III})$ at defect-related local sites are characterized by larger $\tau_{n r}$ due to semi-filled coordination sphere. ${ }^{49-51}$ Thus, a decrease in the lifetime value is expected. In this way, among the series of ${ }^{5} \mathrm{D}_{0}$ lifetimes measured for the Eu(III) local sites, we can correlate the shortest 

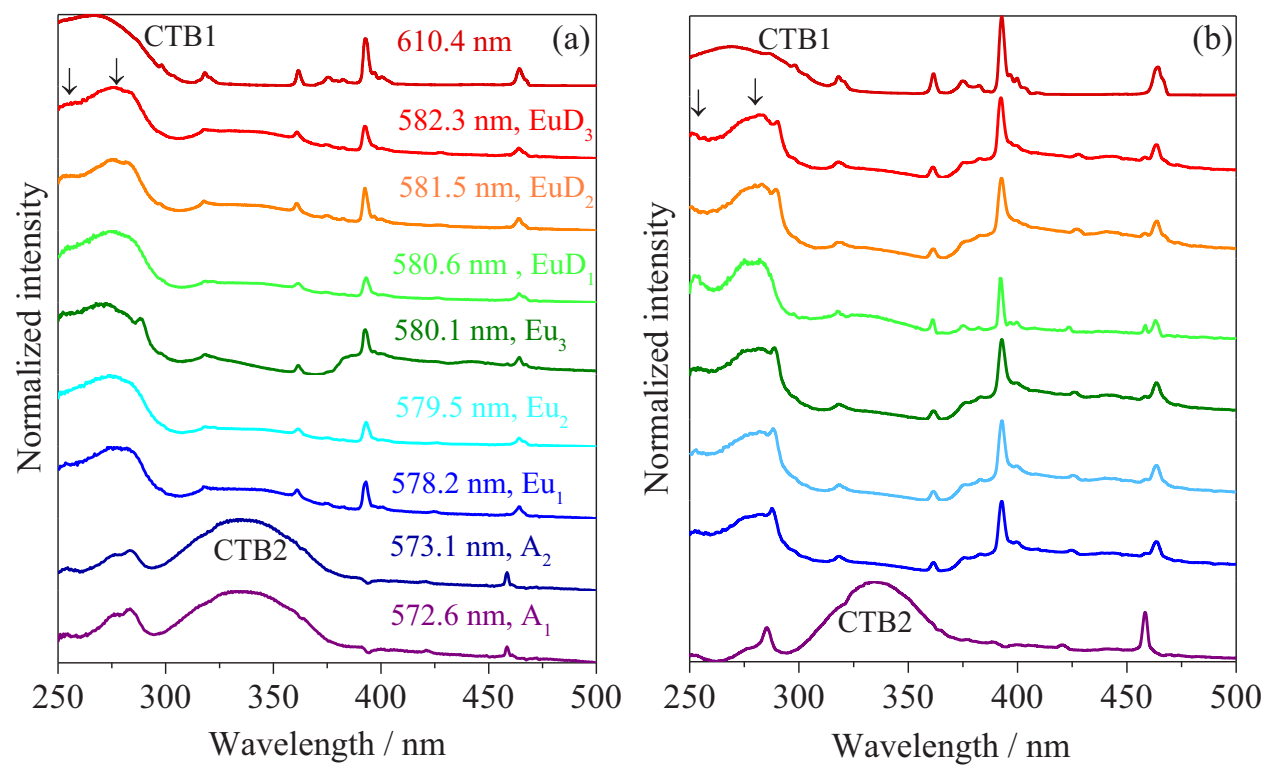

Figure 5. Excitation spectra (14 K) of the (a) Eu-2h and (b) Eu-10h samples monitored at distinct wavelengths around the ${ }^{5} \mathrm{D}_{0} \rightarrow{ }^{7} \mathrm{~F}_{0}$ transitions. CTB1 arises from $\mathrm{Eu}$ in $\mathrm{Ba}$ sites, $\mathrm{CTB} 2$ comes from $\mathrm{Eu}^{3+}-\mathrm{O}^{2-}$ associates and the black arrows represent the two components of the CTB1.

${ }^{5} \mathrm{D}_{0}$ lifetimes monitored around the components at $580.6 \mathrm{~nm}\left(\mathrm{Eu}_{\mathrm{D} 1}\right)$, $581.5 \mathrm{~nm}\left(\mathrm{Eu}_{\mathrm{D} 2}\right)$ and $582.3 \mathrm{~nm}\left(\mathrm{Eu}_{\mathrm{D} 3}\right)$ to $\mathrm{Eu}(\mathrm{III})$ sites associated to the structural defects. Previously, we concluded that the components at $578.2 \mathrm{~nm}\left(\mathrm{Eu}_{1}\right)$ and $579.5 \mathrm{~nm}\left(\mathrm{Eu}_{2}\right)$ come from $\mathrm{Eu}(\mathrm{III})$ in the usual sites of the $\mathrm{Ba}_{2} \mathrm{SiO}_{4}$ network and the lifetime values are in accordance with this assignment. In addition, by increasing the calcination time to $10 \mathrm{~h}$, the lifetime of the ${ }^{5} \mathrm{D}_{0} \rightarrow{ }^{7} \mathrm{~F}_{0}$ components at $578.2 \mathrm{~nm}\left(\mathrm{Eu}_{1}\right)$ and $579.5 \mathrm{~nm}\left(\mathrm{Eu}_{2}\right)$ increases.

As temperature is a crucial parameter in what concerns the balance between radiative and non-radiative transition probabilities, highresolution emission spectra were measured by changing the temperature from $14 \mathrm{~K}$ up to $300 \mathrm{~K}$, Figure 8 . The ${ }^{5} \mathrm{D}_{0} \rightarrow{ }^{7} \mathrm{~F}_{0}$ lines at $580.6 \mathrm{~nm}$ $\left(\mathrm{Eu}_{\mathrm{D} 1}\right), 581.5 \mathrm{~nm}\left(\mathrm{Eu}_{\mathrm{D} 2}\right)$ and $582.3 \mathrm{~nm}\left(\mathrm{Eu}_{\mathrm{D} 3}\right)$ are favored only at low temperatures, Figure 8a, when the non-radiative losses are minimized.

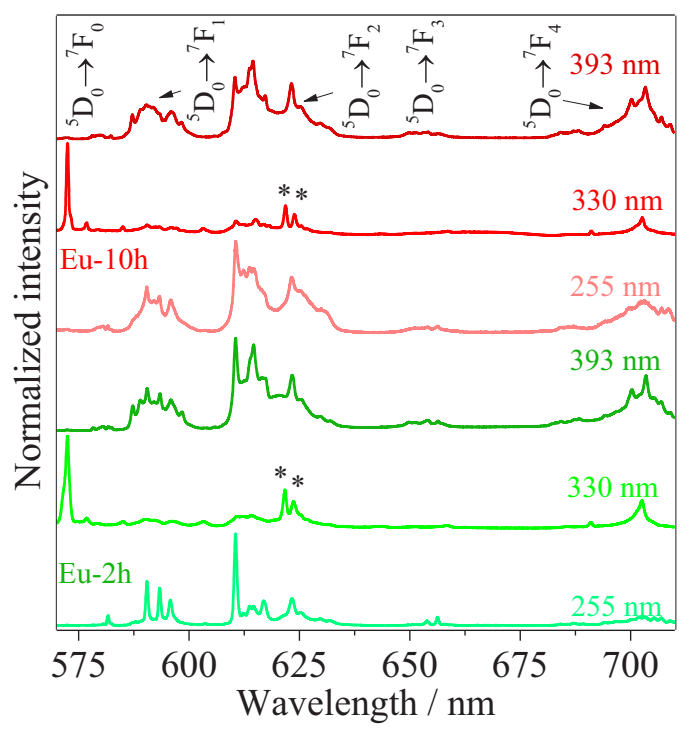

Figure 6. High-resolution emission spectra (14 K) of the Eu(III)-based phosphors monitoring different excitation wavelengths. The $*$ represents the ${ }^{5} \mathrm{D}_{0} \rightarrow{ }^{7} \mathrm{~F}_{2}$ transition components that come from the $\mathrm{Eu}_{\mathrm{A} 1}$ and $\mathrm{Eu}_{\mathrm{A} 2} \mathrm{Eu}$ (III) local sites.
This observation is in accordance with our previous assignment for the nature of the ${ }^{5} \mathrm{D}_{0} \rightarrow{ }^{7} \mathrm{~F}_{0}$ transition components. The components at $590.4 \mathrm{~nm}\left({ }^{5} \mathrm{D}_{0} \rightarrow{ }^{7} \mathrm{~F}_{1}\right.$ transition), $593.3 \mathrm{~nm}\left({ }^{5} \mathrm{D}_{0} \rightarrow{ }^{7} \mathrm{~F}_{1}\right.$ transition $)$, $595.8 \mathrm{~nm}\left({ }^{5} \mathrm{D}_{0} \rightarrow{ }^{7} \mathrm{~F}_{1}\right.$ transition $), 610.4 \mathrm{~nm}\left({ }^{5} \mathrm{D}_{0} \rightarrow{ }^{7} \mathrm{~F}_{2}\right.$ transition $)$ and $623.9 \mathrm{~nm}\left({ }^{5} \mathrm{D}_{0} \rightarrow{ }^{7} \mathrm{~F}_{2}\right.$ transition) reveal analogous thermal dependence, Figures $8 \mathrm{~b}$ and $8 \mathrm{c}$, thus, being related to the $\mathrm{Eu}_{\mathrm{D} 1-3}$ local sites.

Focusing our attention to the potential use of those materials as coatings of deep-UV emitting LEDs, the quantification of the emission is fundamental. The absolute emission quantum yield $(q)$ was measured as a function of the excitation wavelength, namely around $250 \mathrm{~nm}(\mathrm{CTB})$ and within the $f-f$ levels $\left({ }^{5} \mathrm{~L}_{6}\right)$ at $393 \mathrm{~nm}$ and $\left({ }^{5} \mathrm{D}_{2}\right)$ at $464 \mathrm{~nm}$, Figure $3 \mathrm{~b}$. The maximum $q$ values are found at deep-UV excitation (CTB) and increase from $0.058 \pm 0.006$ to $0.11 \pm 0.01$ as the calcination time increases from $2 \mathrm{~h}$ to $10 \mathrm{~h}$, respectively, in good agreement with the above suggestion that the spurious phase contributes to a decrease of the non-radiative decay probability. The achieved $q$ values resemble those of other silicate-based $\mathrm{Eu}$ (III)-phosphors, ${ }^{52}$ but they are lower than those found for classic Eu(III)-based phosphors, such as $\mathrm{Y}_{2} \mathrm{O}_{3}: \mathrm{Eu}(\mathrm{III})$ and $\mathrm{YOF}: \mathrm{Eu}(\mathrm{III})$, Table $\mathrm{S} 2 .{ }^{53}$
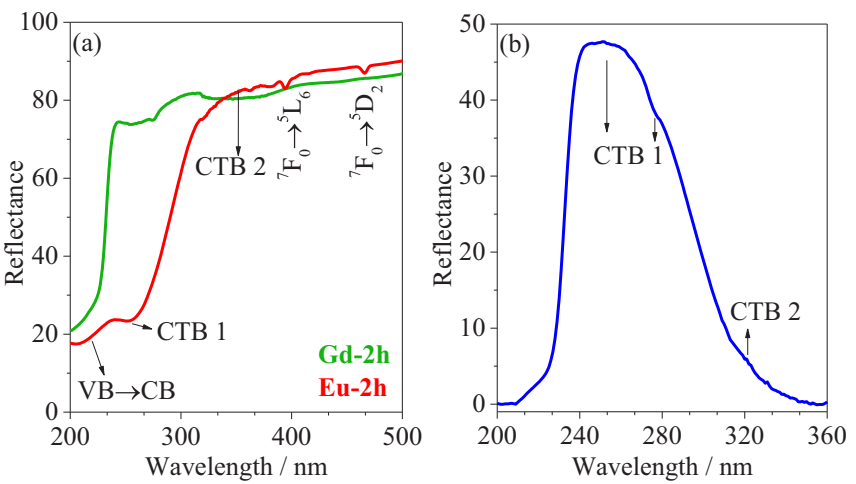

Figure 7. (a) Diffuse reflectance spectra of Gd-2h and Eu-2h. (b) Arithmetic difference between $\mathrm{Gd}-2 \mathrm{~h}$ and $\mathrm{Eu}-2 \mathrm{~h}$-related reflectance spectra in the range of 200-360 nm. CTB 1 comes from Eu inserted in Ba sites and CTB 2 arises from $\mathrm{Eu}^{3+}-\mathrm{O}^{2-}$ associates. 

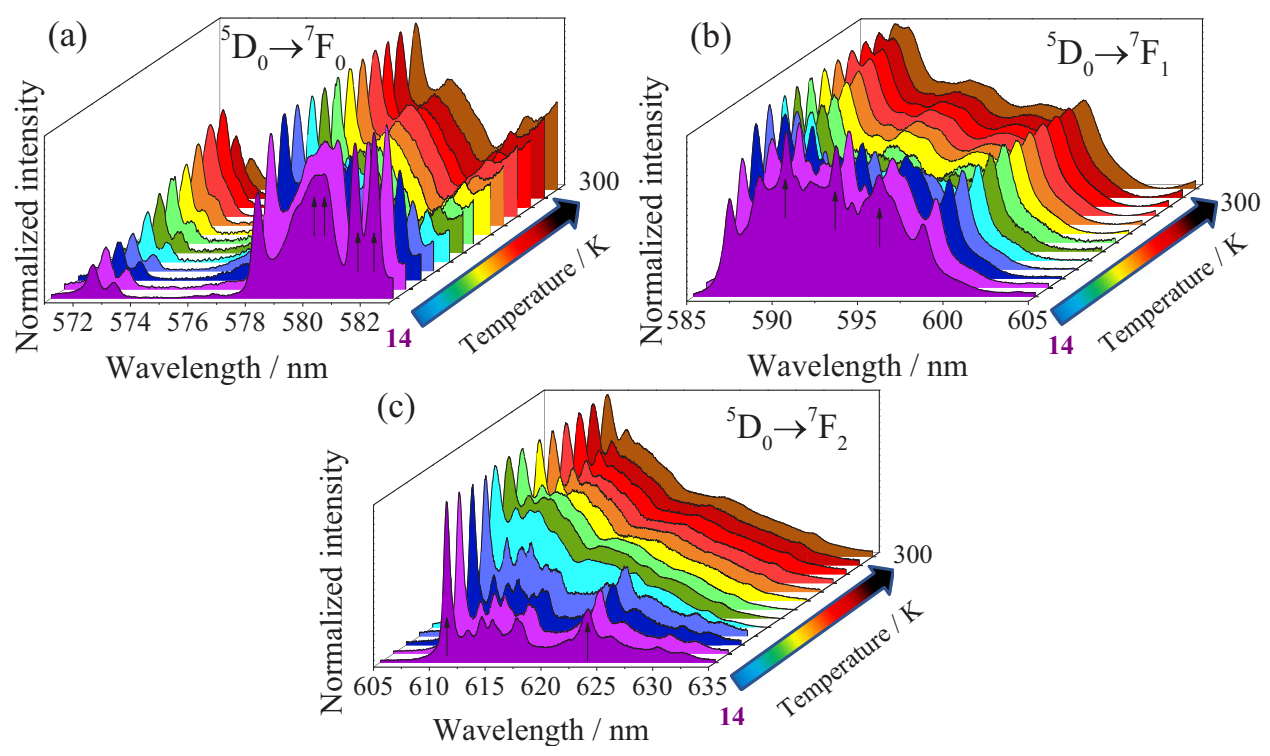

Figure 8. Temperature-dependent emission spectra monitored at $393 \mathrm{~nm}$ of the Eu- $2 \mathrm{~h}$ phosphor in the (a) ${ }^{5} \mathrm{D}_{0} \rightarrow{ }^{7} \mathrm{~F}_{0}$, (b) ${ }^{5} \mathrm{D}_{0} \rightarrow{ }^{7} \mathrm{~F}_{1}$ and (c) ${ }^{5} \mathrm{D}_{0} \rightarrow{ }^{7} \mathrm{~F}_{2}$ transitions region. The black arrows represent the transition components that disappear as the temperature increases.

$\mathrm{Ba}_{2} \mathrm{SiO}_{4}: \mathrm{Eu}(\mathrm{III}) / \mathrm{PMMA}$ film characterization.-Featuring the fabrication of the multifunctional UV and red-emitting LED, redemitting films were fabricated with controlled thickness. To optimize the deposition conditions, the Eu-2h was selected as the red-emitting phosphor since it is easier to process due to its lower calcination time (lower energetic outlay than that of Eu-10h). Then, the best condition (1PMMA:2Eu-2h) was applied to fabricate the PMMA/2Eu-10h film. To optimize the UV absorption, the PMMA:Eu-2h film growth was monitored by UV/visible absorption spectroscopy, Figure S5. The intense band in the deep-UV region at $\sim 225 \mathrm{~nm}$, Figure $\mathrm{S} 5$ (a) is attributed to the PMMA absorption ${ }^{54}$ whereas the band $\sim 265 \mathrm{~nm}$ is related to the above mentioned CTB1, confirming that the phosphor particles are incorporated in the membrane.

The UV absorption spectra were also used to evaluate the optical features as the composite films grow, by monitoring the film absorption in a region $(600 \mathrm{~nm})$ that neither the phosphor nor the polymer absorb, Figure S5 (b). In this case, the absorption increase is mainly ascribed to light scattering by the phosphor particles. ${ }^{55,56}$ The absorbance of the films at $600 \mathrm{~nm}$ reveals a linear increase up to the PMMA:2Eu-2h film, and then tends to a saturation regime at larger phosphor content, suggesting that the phosphor dispersion is homogeneous until the PMMA:2Eu-2h. As the phosphor particles are micro-sized (diameter of $1 \mu \mathrm{m}),{ }^{26}$ it is expected that the precursor suspension becomes unstable as the phosphor amount increases, leading to a non-homogeneous deposition of the particles. Also, considering that the phosphor particle surface is non-ionic, weak interactions like Van der Waals forces are the main driving forces that maintain the suspension stable, being strongly influenced by the particle concentration, and leading to particle coagulation at high concentration. ${ }^{55,57}$

The film thickness decreases as the phosphor amount increases from the proportion of 1 PMMA:1 Eu2-h, Table III. This tendency is correlated with the decrease of the PMMA content in the film composition. ${ }^{28}$

Under UV exposition (255 nm), the PMMA:2Eu-10h exhibits bright red luminescence at naked eyes, Figure 9a, confirming the successful incorporation of the Eu-10h phosphor in the polymeric matrix. The excitation spectrum, Figure 9b, of PMMA:2Eu-10h, is dominated by the $\mathrm{Eu}^{3+} \rightarrow \mathrm{O}^{2-} \mathrm{CTB} 1$ and $f-f \mathrm{Eu}(\mathrm{III})$ transition in accordance with the previously reported Eu-10h excitation spectra, Figure $3 \mathrm{~b}$.

All films emit red light upon $255 \mathrm{~nm}$ radiation exposition, Figure $9 \mathrm{c}$, but there is a deviation of the overall emission color from the red toward the blue spectral region as the phosphor particle concentration decreases in the PMMA matrix, as represented in CIE chromatic- ity diagram, Figure $9 \mathrm{~d}$. This deviation is associated with the intrinsic PMMA emission (Figure S6) in the blue spectral region that has high contribution in the emission pattern as the phosphor content decreases.

The luminous flux of the films enhances as the phosphor amount increases up to the proportion of PMMA:2Eu-2h, Table III. This tendency is directly correlated with the above-mentioned film coagulation as the phosphor amount increases. The PMMA:2Eu-10h film showed the best luminous flux, confirming that this is the ideal condition. Furthermore, the luminous flux values of PMMA:2Eu- $2 \mathrm{~h}$ and PMMA:2Eu-10h are higher than the values found for the powder phosphors, Table III, suggesting that the phosphor dispersion in PMMA affects the $\mathrm{Ba}_{2} \mathrm{SiO}_{4}$ surface since as the particles are micro-sized, it is expected that PMMA does not penetrate inside the particles.

To understand the changes in the $\mathrm{Ba}_{2} \mathrm{SiO}_{4}$ structure after the phosphor dispersion in PMMA, the PMMA:2Eu-10h film was chosen as a representative sample since it showed the highest luminous flux. The excitation and emission spectra of the PMMA:2Eu-10h film, Figure $\mathrm{S} 7$, are similar to those ones related to the Eu-10h sample, except in the relative intensity of some ${ }^{5} \mathrm{D}_{0} \rightarrow{ }^{7} \mathrm{~F}_{0}$ transitions, Figure $4 \mathrm{a}$. For the PMMA:2Eu-10h film, only five components for the ${ }^{5} \mathrm{D}_{0} \rightarrow{ }^{7} \mathrm{~F}_{0}$ transition at $572.6 \mathrm{~nm}\left(\mathrm{Eu}_{\mathrm{A} 1}\right), 578.2 \mathrm{~nm}\left(\mathrm{Eu}_{1}\right), 579.6 \mathrm{~nm}\left(\mathrm{Eu}_{2}\right), 580.1 \mathrm{~nm}$ $\left(\mathrm{Eu}_{3}\right)$, and $582.3 \mathrm{~nm}\left(\mathrm{Eu}_{\mathrm{D} 3}\right)$ are noticed, Figure $4 \mathrm{a}$.

The excitation spectra monitored around each ${ }^{5} \mathrm{D}_{0} \rightarrow{ }^{7} \mathrm{~F}_{0}$ components (Figure S7) are quite similar to those ones acquired for Eu-10h (Figure 5), confirming the preservation of the Eu(III) local environ-

Table III. Film thickness and luminous flux compared to the powder phosphors.

\begin{tabular}{ccc} 
Sample & Thickness $/ \mu \mathrm{m}$ & Luminous flux $/ \times 10^{-4} \mathrm{~lm}$ \\
\hline PMMA:0.25Eu-2h & $26 \pm 2$ & 0 \\
PMMA:1Eu-2h & $88 \pm 4$ & $3.8 \pm 0.1$ \\
PMMA:2Eu-2h & $72 \pm 3$ & $5.9 \pm 0.2$ \\
PMMA:3Eu-2h & $55 \pm 6$ & $4.3 \pm 0.2$ \\
PMMA:4Eu-2h & $17 \pm 2$ & $2.5 \pm 0.1$ \\
PMMA:2Eu-10h & $68 \pm 2$ & $7.9 \pm 0.3$ \\
Eu-2h & $*$ & $4.5 \pm 0.2$ \\
Eu-10h & $*$ & $5.4 \pm 0.2$
\end{tabular}

*Samples as powders. 
(a)

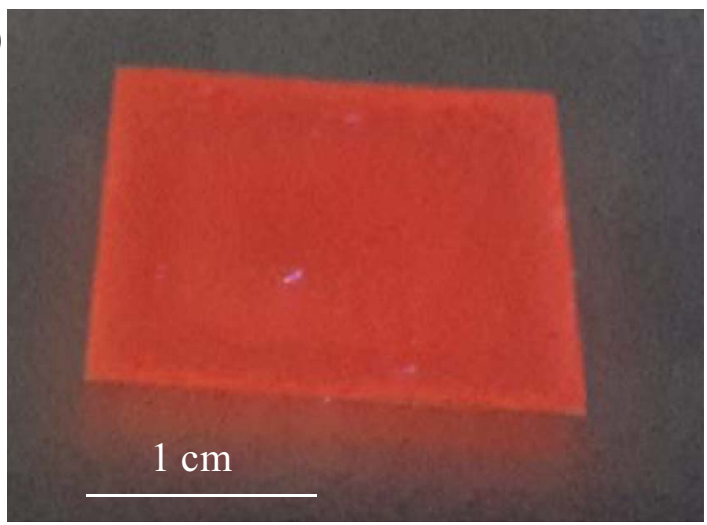

(c)

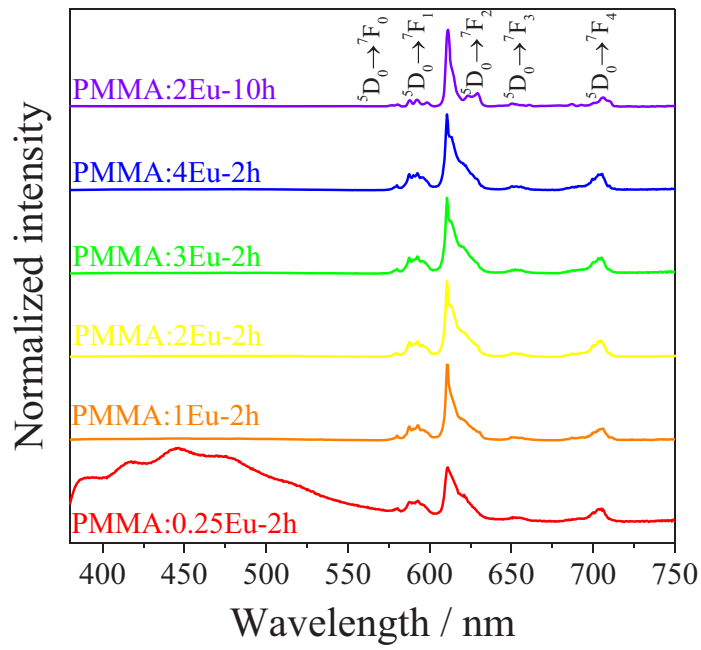

(b)

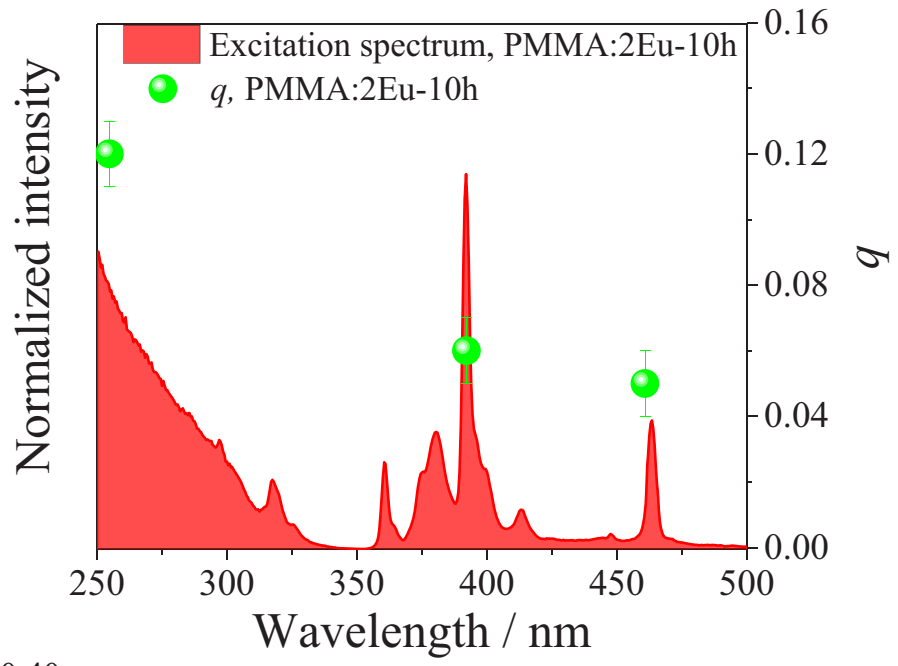

(d)

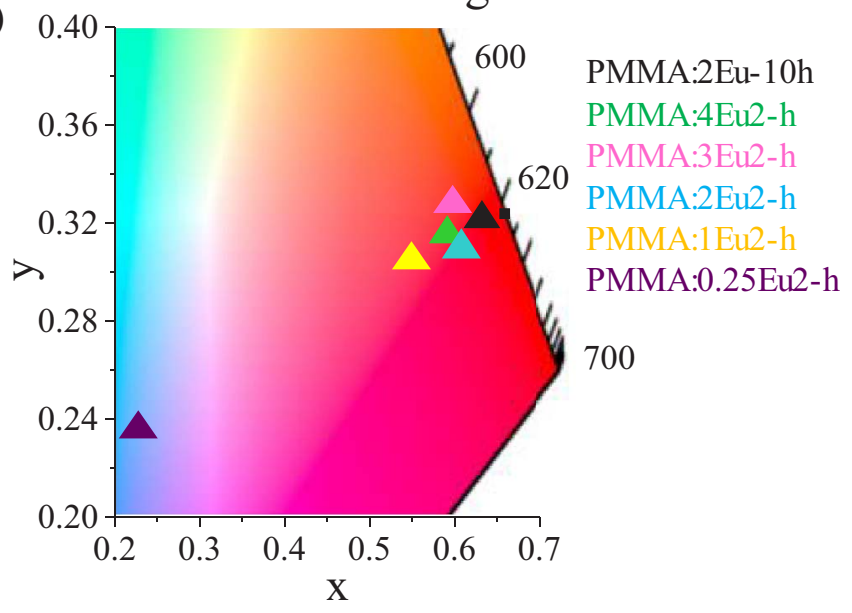

Figure 9. Photo of the PMMA:2Eu-10h film under UV radiation (255 nm) exposition. (b) Absolute emission quantum yield ( $q$ ) for the PMMA:2Eu-10h film compared to its excitation spectrum. (c) Emission spectra ( $300 \mathrm{~K})$ monitored at $255 \mathrm{~nm}$ of the films. (d) CIE chromaticity diagram of the films monitored at $255 \mathrm{~nm}$.

ment after the dispersion in PMMA. Yet, the ${ }^{5} \mathrm{D}_{0} \rightarrow{ }^{7} \mathrm{~F}_{0}$ transitions at $580.2 \mathrm{~nm}\left(\mathrm{Eu}_{\mathrm{D} 1}\right), 581.6 \mathrm{~nm}\left(\mathrm{Eu}_{\mathrm{D} 2}\right)$, and $582.3 \mathrm{~nm}\left(\mathrm{Eu}_{\mathrm{D} 3}\right)$ reveal a decrease in their relative intensity after the dispersion in PMMA, when compared to the component at $578.2 \mathrm{~nm}$ (Eu1), Figure 4a, suggesting that the phosphor dispersion fills the lacking oxy ion positions, suppressing defects, probably located on the surface of $\mathrm{Ba}_{2} \mathrm{SiO}_{4}: \mathrm{Eu}(\mathrm{III})$ particles. Thus, the $\mathrm{Ba}_{2} \mathrm{SiO}_{4}: \mathrm{Eu}$ (III) dispersion in PMMA confirms that the $\mathrm{Eu}_{\mathrm{D} 1-3}$ defects are located mostly on the particle surface.

Selective emission decay curves (Figures S8) for the PMMA:2Eu10h sample were monitored around each one of the five ${ }^{5} \mathrm{D}_{0} \rightarrow{ }^{7} \mathrm{~F}_{0}$ components at $14 \mathrm{~K}$ and the calculated ${ }^{5} \mathrm{D}_{0}$ lifetime values are also included in Table II. The ${ }^{5} \mathrm{D}_{0}$ lifetime values of the components at $580.2 \mathrm{~nm}\left(\mathrm{Eu}_{\mathrm{D} 1}\right)$ and $582.3 \mathrm{~nm}\left(\mathrm{Eu}_{\mathrm{D} 3}\right)$ decrease after the $\mathrm{Eu}-10 \mathrm{~h}$ dispersion in PMMA, Table II, confirming that the concentration of these defects decreases, in accordance with the above-cited structural changes. Finally, the emission quantum yield of the PMMA:2Eu$10 \mathrm{~h}$ film is statistically the same compared to the Eu-10h phosphor, Figure $9 \mathrm{~b}$, confirming that the dispersion of the phosphor does not quench the $\mathrm{Eu}(\mathrm{III})$ emission.

Therefore, the finds reported here confirm that by dispersing $\mathrm{Ba}_{2} \mathrm{SiO}_{4}: \mathrm{Eu}$ (III) red-emitting phosphors in PMMA, high-brightness deep-UV-to-red downshifting converter films were fabricated, with potential to be applied in the future as coatings of multifunctional UV/red-emitting LEDs for indoor farming, being that PMMA decreases the concentration of defect-related Eu(III) local sites without any quenching of the $\mathrm{Eu}(\mathrm{III})$ emission, that is a remarkable ad- vantage taking into consideration the balance between non-radiative and radiative decay probabilities from the $\mathrm{Eu}(\mathrm{III}){ }^{5} \mathrm{D}_{0}$ emitting state.

\section{Conclusions}

Herein, $\mathrm{Ba}_{2} \mathrm{SiO}_{4}$ : $\mathrm{Eu}$ (III) deep-UV-to-red downshifting converter phosphor was synthesized by the sol-gel route and its incorporation in the PMMA polymer was introduced, producing films with tunable red-emission intensity and thickness. The phosphor, in both powder or film forms, emits in the red spectral region characteristic of Eu(III) into the $\mathrm{Ba}_{2} \mathrm{SiO}_{4}$ network. The sol-gel synthesis was carried out at $1100^{\circ} \mathrm{C}$ and the increase of the annealing time from $2 \mathrm{~h}$ to $10 \mathrm{~h}$ decreases the amount of $\mathrm{BaSiO}_{3}$ spurious phase and enhances the absolute quantum yield from $0.058 \pm 0.006$ to $0.110 \pm 0.010$. $\mathrm{Eu}(\mathrm{III})$ is inserted in 8 non-equivalent local sites, 2 coming from $\mathrm{Eu}^{3+} \mathrm{O}^{2-}$ associates, 2 arising from the $\mathrm{Ba}$ site replacement in the $\mathrm{Ba}_{2} \mathrm{SiO}_{4}$ matrix, 1 from the $\mathrm{Ba}$ site replacement in the $\mathrm{BaSiO}_{3}$ network and 3 defectrelated sites. The phosphor dispersion in PMMA does not quench the $\mathrm{Eu}(\mathrm{III})$ emission and also undoes the Eu defect sites. Therefore, the $\mathrm{Ba}_{2} \mathrm{SiO}_{4}$ : $\mathrm{Eu}$ (III)/PMMA films show potential to be used as coatings of deep-UV-emitting LEDs $(250 \mathrm{~nm})$, making a device that combines both UV and red-emission, important to disinfection and plant circadian rhythm control applications in indoor farms. 


\section{Acknowledgments}

The authors are thankful to the Brazilian agencies FAPESP and $\mathrm{CNPq}$ for the financial research support. Airton G. Bispo-Jr is particularly grateful to the São Paulo research Foundation (FAPESP) for the award of some scholarships (grant No. 2015/10394-1, 2016/204219, and 2017/21995-1). Funding was also provided by CICECOAveiro Institute of Materials, FCT Ref. UID/CTM/50011/2019), and WINLEDs (POCI-01-0145-FEDER-030351) financed by national funds through the FCT/MEC and co-financed by FEDER under the PT2020 Partnership through European Regional Development Fund (ERDF) in the frame of Operational Competitiveness and Internationalization Programme (POCI). Andrei Kovalevsky from CICECOAveiro Institute of Materials is acknowledged for help in the heat treatments, and Rosário T. Soares from Chemistry department of University of Aveiro for XRD measurements.

\section{ORCID}

Airton G. Bispo-Jr (D) https://orcid.org/0000-0002-1501-8815

Ana M. Pires (1D https://orcid.org/0000-0001-9607-0510

\section{References}

1. J. Cho, J. H. Park, J. K. Kim, and E. F. Schubert, Laser Photonics Rev., 11, 1600147 (2017).

2. T. Pulli, T. Donsberg, T. Poikonen, F. Manoocheri, P. Karha, and E. Ikonen, Light: Sci. Appl., 4, e332 (2015)

3. Z. Xia and Q. Liu, Prog. Mater. Sci., 84, 59 (2016)

4. M. Jacoby, Chem. Eng. News, 96, 28 (2018).

5. P. M. Pattison, M. Hansen, and J. Y. Tsao, C. R. Phys., 19, 134 (2018).

6. P. M. Pattison, J. Y. Tsao, G. C. Brainard, and B. Bugbee, Nature, 563, 493 (2018).

7. A. Wunsch and K. Matuschka, Photomed. Laser Surg., 32, 93 (2014).

8. R. M. Klein, Biol. Rev. Cambridge Philos. Soc., 67, 199 (1992).

9. D. C. Negelspach, S. Kaladchibachi, and F. Fernandez, Proc. R. Soc. B, 285, 1288 (2018).

10. T. A. LeGates, D. C. Fernandez, and S. Hattar, Nat. Rev. Neurosci., 15, 443 (2014).

11. N. Yeh, P. Yeh, N. Shih, O. Byadgi, and T. C. Cheng, Renew. Sust. Energ. Rev., 32 611 (2014)

12. M. C. Snowden, K. R. Cope, and B. Bugbee, PLoS One, 6, 1 (2016).

13. A. E. Stapleton, Plant Cell, 4, 1353 (1992).

14. N. Yeh, T. J. Ding, and P. Yeh, Renewable Sustainable Energy Rev., 51, 55 (2015).

15. P. S. C. Schulze, L. A. Barreira, H. G. C. Pereira, J. A. Perales, and J. C. S. Varela Trends Biotechnol., 32, 422 (2014).

16. S. Demotes-Mainarda, T. Pérona, A. Corot, J. Bertheloot, J. L. Gourriere, S. Pelleschi-Travier, L. Crespel, P. e. Morela, L. Huché-Théliera, R. Boumaza, A. Vian, V. Guérin, N. Leduc, and S. Sakr, Environ. Exp. Bot., 121, 4 (2016).

17. M. Kneissl, T. Seong, J. Han, and H. Amano, Nat. Photonics, 13, 233, (2019).

18. C. Bowker, A. Sain, M. Shatalov, and J. Ducoste, Water Res., 45, 2011 (2011).

19. M. Mori, A. Hamamoto, A. Takahashi, M. Nakano, N. Wakikawa, and S. Tachibana, Med. Biol. Eng. Comput., 45, 123 (2007).

20. A. C. Chevremont, A. Farnet, M. Sergent, B. coulomb, and J. L. Boudenne, Desalination, 285, 219 (2012).

21. T. Meng, G. Ren, G. Wang, and Yan Ma, Appl. Microbiol. Biotechnol., 103, 6369 (2019)
22. Y. Li, M. Dvorak, P. N. Nesterenko, N. Nuchtavorn, and M. Mack, Sens. Actuators, $B$, 255, 1238 (2018).

23. J. Park, J. Kyu Kim, J. Cho, and T. Seong, ECS J. Solid State Sci. Technol., 6, Q42 (2017).

24. E. Pavitra, G. S. R. Raju, J. Oh, L. K. Bharat, J. H. Jeong, Y. Suk Huh, and J. S. Yu, Dyes Pigm., 142, 447 (2017).

25. Z. Wang, S. Guo, Q. Li, Xing Zhang, T. Li, P. Li, Z. Yang, and Q. Guo, Physica B, 411, 110 (2013)

26. A. G. Bispo-Jr, D. A. Ceccato, S. A. M. Lima, and Ana. M. Pires, RSC Adv., 7, 53752 (2017).

27. A. G. Bispo-Jr, S. A. M. Lima, and A. M. Pires, J. Lumin., 199, 372 (2018)

28. A. G. Bispo-Jr, N. A. Oliveira, C. X. Cardoso, S. A. M. Lima, A. E. Job, I. O. Osorio-Román, C. S. Danna, and A. M. Pires, Mater. Chem. Phys., 217, 160 (2018).

29. A. G. Bispo-Jr, S. A. M. Lima, S. Lanfredi, F. R. Praxedes, and A. M. Pires, J. Lumin., 214, 116604 (2019).

30. Q. Zhou, L. Dolgov, A. M. Srivastava, Lei Zhou, Zhengliang Wang, Jianxin Shi, Miroslav D. Dramicanin, Mikhail G. Brik, and Mingmei Wu, J. Mater. Chem. C, 6, 2652 (2018).

31. S. Adachi, J. Lumin., 202, 263 (2018).

32. S. Adachi, J. Lumin., 197, 119 (2018).

33. F. Zhou, T. Wang, Z. Li, and Y. Wang, J. Lumin., 30, 1303 (2015).

34. P. A. Raymundo-Pereira, D. A. Ceccato, A. G. Bispo-Jr, M. F. S. Teixeira, S. A. M. Lima, and Ana. M. Pires, $R S C A d v$., 6, 104529 (2016).

35. P. A. Santa-cruz and F. S. Teles, Spectra Lux Software. Verion 2.0 RENAMI, 2003.

36. A. Romero Serrano, A. C. Ramirez, B. Zeifert, M. H. Lopez, and A. H. Ramirez, Glass Phys. Chem., 36, 171 (2010).

37. K. A. Denault, J. Brgoch, S. D. Kloß, M. W. Gaultois, J. Siewenie, K. Page, and R. Seshadri, ACS Appl. Mater. Interfaces, 7, 7264 (2015).

38. Y. Jia, W. Sun, R. Pang, T. Ma, D. Li, H. Li, S. Zhang, J. Fu, L. Jiang, and C. Li, Mater. Des., 90, 218 (2016).

39. A. M. Pires and M. R. Davolos, Chem. Mater, 13, 21 (2001).

40. D. Avram, M. Sanchez-Dominguez, B. Cojocaru, M. Florea, V. Parvulescu, and C. Tiseanu, J. Phys. Chem. C, 119, 16303 (2015).

41. H. Liu, S. Guo, Y. Hao, H. Wang, and B. Xu, J. Lumin., 132, 2908 (2012).

42. D. Van Der Voort, G. J. Dirksen, and G. Blasé, J. Phys. Chem. Solids, 53, 219 (1992).

43. L. D. Carlos, R. A. S. Ferreira, V. Z. Bermudez, C. Molina, L. A. Bueno, and S. J. L. Ribeiro, Phys. Rev. B, 60, 10042 (1999).

44. A. M. Pires, M. R. Davolos, and O. L. Malta, J. Lumin., 72-74, 244 (1997)

45. K. Fiaczyk and E. Zych, RSC Adv., 6, 91836 (2016).

46. C. B. Liu, R. A. S. Ferreira, F. A. Almeida Paz, A. Cadiau, L. D. Carlos, L. S. Fu, J. Rocha, and F.-N. Shi, Chem. Commun., 48, 7964 (2012).

47. L. J. Dacanin, S. R. Lukic, D. M. Petrovic, M. Nikolic, and M. D. Dramicanin, Physica B, 406, 2319 (2011).

48. S. K. Gupta, M. Mohapatra, S. Kaity, V. Natarajan, and S. V. Godbole, J. Lumin., 132, 1329 (2012).

49. A. Magyar, W. Hu, T. Shanley, M. E. Flatte, E. Hu, and I. Aharonovich, Nat. Commun., 5, 3523 (2013).

50. I. E. Kolesnikov, A. V. Povolotskiy, D. V. Mamonova, E. Lähderanta, A. A. Manshina, and M. D. Mikhailov, RSC Adv., 6, 76533 (2016)

51. S. V. Eliseeva and J. G. Bunzli, Chem. Soc. Rev., 39, 189 (2010).

52. Y. Zhang, J. Xu, Q. Cui, and B. Yang, Sci. Rep., 7, 42464 (2017).

53. W. M. Yenand and M. J. Weber, The CRC Press, Laser and Optical Science and Technology Series, New York, 2004.

54. R. Bisen, J. Tripathi, A. Sharma, Ayush Khare, Yogesh Kumar, and S. Tripathi, Vacuum, 152, 65 (2018).

55. S. A. Camacho, P. H. B. Aoki, C. J. L. Constantino, R. F. Aroca, and A. M. Pires, J. Alloys Compd., 541, 365 (2012).

56. G. Yan-Bao, W. De-Guo, L. Shu-Hai, and Z. Si-Wei, Surf. Coat. Technol., 205, 2924 (2011).

57. S. E. Moya, A. Ilie, J. S. Bendall, J. L. Hernandez-Lopez, and J. Ruiz-Garcia, and W. T. S. Macromol. Chem. Phys., 208, 603 (2007). 